\author{
TOMASZ KRZYŻowsKI \\ https://orcid.org/0000-0001-7193-5661 \\ Ośrodek Badań nad Kulturą Ormiańską w Polsce \\ Polska Akademia Umiejętności, Kraków
}

\title{
JAN HASSO AGOPSOWICZ (1915-1982) ORMIANIN, BIBLIOFIL, TWÓRCA EKSLIBRISÓW
}

\begin{abstract}
Abstrakt: W artykule zaprezentowano biografię Jana Hasso Agopsowicza (19151982), polskiego Ormianina, zasłużonego dla środowiska ormiańskiego w Polsce. Urodził się w Kociubińcach w Galicji Wschodniej w ormiańskiej rodzinie ziemiańskiej. W latach 1931-1938 studiował w Rzymie w Papieskim Kolegium Ormiańskim i na Uniwersytecie Gregoriańskim, przygotowując się do przyjęcia święceń kapłańskich w obrządku ormiańskim. W październiku 1938 roku zrezygnował z finalizacji studiów teologicznych i wrócił do Polski. Po drugiej wojnie światowej osiadł w Nowym Sączu, gdzie był kierownikiem laboratorium analitycznego w szpitalu miejskim. Agopsowicz dużą uwagę przywiązywał do sytuacji diaspory ormiańskiej w Polsce oraz aktywności środowiska ormiańskiego. Chcąc zapewnić opiekę duszpasterską Ormianom katolikom w Polsce i przetrwanie obrządku ormiańskiego, interweniował w Stolicy Apostolskiej oraz u prymasa Stefana Wyszyńskiego. Równocześnie angażował się w działalność artystyczną. Jego pasją było tworzenie ekslibrisów, których zaprojektował 240. Zainteresowania Agopsowicza historią i kulturą ormiańską, jak również liczne kontakty z Ormianami zaowocowały powstaniem kilkudziesięciu ekslibrisów o tematyce ormiańskiej. Ponadto zgromadził obszerny księgozbiór dotyczący tematyki armenistycznej w różnych językach. Zmarł w Nowym Sączu, został pochowany na cmentarzu Rakowickim w Krakowie.
\end{abstract}

Słowa kluczowe: Jan Hasso Agopsowicz, Ormianie polscy, Papieskie Kolegium Ormiańskie, Nowy Sącz, ekslibrisy, Kościół ormiańskokatolicki w Polsce 


\section{Środowisko rodzinne i lata młodzieńcze}

Ormiańska rodzina Hasso Agopsowiczów od kilku pokoleń pielęgnowała tradycje ziemiańskie. Pradziadek Jana, Grzegorz Michał (1781-1844), był właścicielem Kułaczkowiec pod Kołomyją, a jego syn Józef (1828-1878) - dzierżawcą innego majątku ziemskiego (Skopówka). W życiorysie tego drugiego wydarzył się ciekawy epizod, który wart jest odnotowania. Gdy w 1872 roku pojechał do Krakowa, poznał tam przypadkowo Jana Matejkę, któremu pozował do obrazu Batory pod Pskowem, wcielając się w postać monarchyํ․ Syn Józefa, a ojciec Jana, Jakub Kajetan Hasso Agopsowicz (1876-1929), studiował chemię i historię sztuki w Wiedniu, a po skończeniu studiów - podobnie jak jego antenaci - zajął się uprawą ziemi w Kociubińcach na południe od Tarnopola we wschodniej Galicji² i ułożył sobie życie rodzinne. Ze związku z Karoliną Wąsowicz (1884-1934) w 1910 roku urodziła się córka Adela, a dwa lata później na świat przyszła Maria, która zmarła w wieku niemowlęcym³ ${ }^{3}$. W 1911 roku Jakub Agopsowicz nabył majątek Popielniki oddalony 16 kilometrów na południowy zachód od Śniatynia. Gospodarstwo składało się z 560 morgów pola ornego, nie licząc pastwisk i łąk. Był dobrym gospodarzem; prowadzone przez niego dwa majątki w Popielnikach i Kociubińcach uchodziły za wzorowe, a z jego wiedzy korzystali znajomi, poszukający porady w sprawach własnych posiadłości ziemskich. Nawet po klęsce pożaru i utracie całorocznych plonów potrafił zapewnić stabilną sytuację oraz byt rodzinie i pracownikom ${ }^{4}$.

W Kociubińcach właśnie, 25 października 1915 roku, urodził się Jan Józef Hasso Agopsowicz. Był to czas burzliwy, trwała pierwsza wojna światowa. Majątek Agopsowiczów zajęły wojska rosyjskie, a żołnierze wdarli się do pokoju z niemowlęciem zaledwie kilka godzin po jego narodzinach. Kolejne lata wojny oraz konflikt polsko-ukraiński odcisnęły swoje piętno na rodzinie Agopsowiczów. Wtargnięcia wojsk, które rekwirowały żywność i konie, zajmowały kwatery mieszkalne oraz dokonywały zniszczeń, były niemal na porządku dziennym. Znacząco ucierpiały Popielniki, splądrowane przez oddziały ukraińskie. Jakuba Agopsowicza Ukraińcy osadzili w więzieniu w Kołomyi, a następnie w Stanisławowie. W 1919 roku zdołał zbiec, zmuszony był jednak ukrywać się w okolicach

1 J. Koszyk, L. Mazan, W Nowym Sączu mieszka wnuk Batorego!, „Przekrój”, 1980, nr 1825, s. 10. Historię tę opisał Abgar Sołtan (Kajetan Abgarowicz) w opowiadaniu pt. Król Polski zamieszczonym w zbiorze: Widziane i odczute. Szkice i opowiadania, Kraków 1904, s. 261-278.

2 Zbiory Barbary Agopsowicz Krasowskiej w Krakowie (dalej: ZBAK): J. Hasso Agopsowicz, Genealogia rodu Hasso Agopsowiczów 1428-1978, Nowy Sącz 1978, mszps, s. 37-39.

3 J. Hasso Agopsowicz, Popielniki, „Gdzie szum Prutu”, 12, 2001, 2, s. 85.

4 Ibidem, s. 87-89; M. Agopsowicz, Kresowe Pokucie. Rzeczpospolita Ormiańska, Łomianki 2014, s. 145. 
Kociubiniec z obawy przed grasującymi tam bandami ukraińskimi ${ }^{5}$.

Pierwsze pięć lat życia Jan Agopsowicz spędził $\mathrm{w}$ majątku ziemskim w Kociubińcach. W 1920 roku przeniósł się wraz z matką i siostrą do Stanisławowa, gdzie zamieszkali przy ul. Moniuszki. Przeprowadzka umożliwiła dzieciom lepsze warunki edukacyjne: Adela uczęszczała do gimnazjum, a Jan rozpoczął wkrótce naukę w szkole powszechnej im. Adama Mickiewicza. Okres świąt Bożego Narodzenia i Wielkanocy oraz wakacje cała rodzina spędzała w Popielnikach. Ze Stanisławowa dojeżdżali pociągiem do stacji Widynów lub Śniatyn-Załucze, a następnie faetonem zaprzężonym w konie do majątku oddalonego o kilkanaście kilometrów. Zimą podróżowano saniami, zdając się na instynkt koni, gdyż pola i drogi były zasypane śniegiem, co utrudniało orientację w terenie. Popielniki i okolice były malowniczą krainą na Pokuciu położoną nad Czeremoszem, przy granicy z Rumunią, z bogatą fauną i florą,

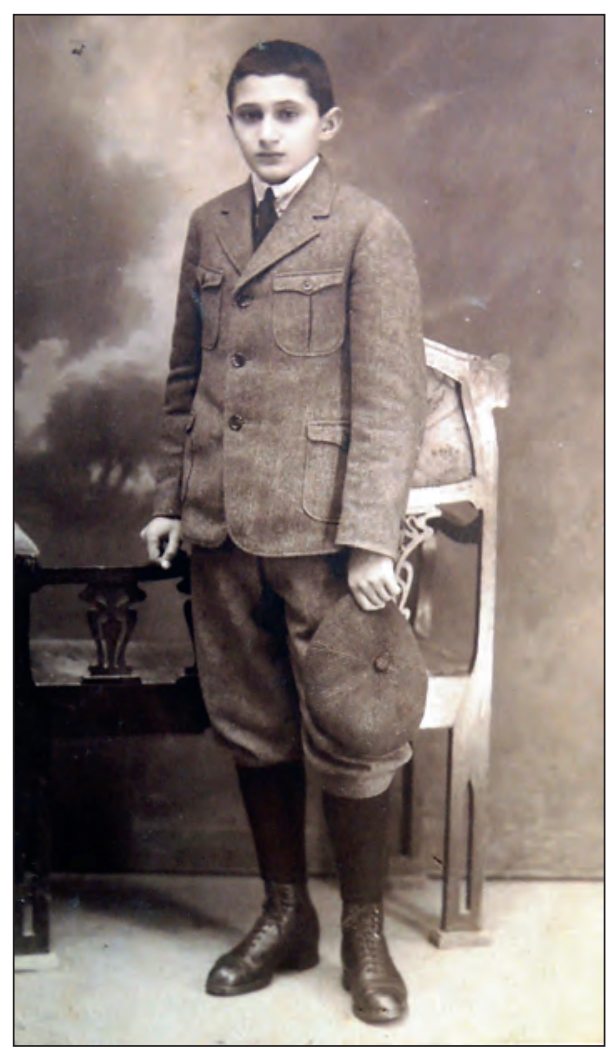

1. Jan Hasso Agopsowicz, Stanisławów, 1924, Zbiory Barbary Agopsowicz Krasowskiej w Krakowie krystalicznie czystym powietrzem. Przy dobrej pogodzie w oddali dostrzec można było pasmo Czarnohory z jej najwyższym szczytem, Howerlą ${ }^{6}$. Beztroskie chwile dzieciństwa Jan spędzał na zabawach i przechadzkach po okolicy.

Jakub Agopsowicz wychowywał swoje dzieci na ludzi pracowitych i odpowiedzialnych, dlatego powierzał im drobne obowiązki w gospodarstwie. W ten sposób mogły zdobyć doświadczenie i umiejętności przydatne w dorosłym życiu. Jan bacznie obserwował prace polowe w okresie żniw i sianokosów, towarzyszył ojcu podczas objazdu pól uprawnych, dostrzegał piękno nieskażonej przyrody, zachwycał się bogactwem miejscowego folkloru, w tym zwyczajami i potrawami huculskimi ${ }^{7}$. Po ukończeniu szkoły powszechnej kontynuował edukację w renomowanym gimnazjum klasycznym im. Mieczysława Romanowskiego w Stani-

${ }^{5}$ J. Hasso Agopsowicz, Popielniki, s. 85-86.

${ }^{6}$ Ibidem, s. 86-87; B. Agopsowicz-Krasow ska, Jan Józef Hasso Agopsowicz, „Gdzie szum Prutu", 12, 2001, 2, s. 84.

7 J. Hasso Agopsowicz, Popielniki, s. 88-91. 
sławowie. Szkoła o tradycjach sięgających XVIII stulecia umożliwiała solidny rozwój intelektualny oraz wychowanie w duchu polskiego patriotyzmu.

W 1929 roku zmarł Jakub Agopsowicz. Niedługo potem, po ukończeniu zaledwie czwartej klasy gimnazjalnej ${ }^{8}$ i w wieku niespełna szesnastu lat, Jan Agopsowicz zdecydował się na wyjazd do Rzymu i wstąpienie do Papieskiego Kolegium Ormiańskiego. Przybył tam jako alumn archidiecezji lwowskiej obrządku ormiańskiego 16 lipca 1931 roku w towarzystwie trzech kolegów: Kazimierza Roszki, Grzegorza Petrowicza i Krzysztofa Donigiewicza9.

\section{Studia uniwersyteckie w Rzymie}

Papieskie Kolegium Ormiańskie (Pontificio Collegio Armeno) w Rzymie powstało w 1883 roku z inicjatywy kardynała Andona Hassouna w celu formacji kleryków obrządku ormiańskiego. Przyjmowano kandydatów w wieku od 14 do 22 lat, którzy ukończyli podstawowy etap edukacji oraz znali język łaciński. Alumni przez pierwszy rok pobytu w Kolegium uczyli się języka ormiańskiego i włoskiego oraz liturgii ormiańskiej. Potem rozpoczynali studia filozoficzno-teologiczne na Papieskim Uniwersytecie Gregoriańskim w Rzymie ${ }^{10}$. Przed wstąpieniem kandydat zobowiązany był wypełnić ankietę podpisaną przez swojego biskupa ordynariusza. Zawierała ona podstawowe dane personalne, daty przyjęcia sakramentów, informacje o rodzicach i przebiegu edukacji. Jeden z punktów dotyczył znajomości języka ormiańskiego. Agopsowicz wyjaśnił, że zna wystarczająco dobrze łacinę i może rozpocząc studia w tym języku. W kwestionariuszu pytano też o motywy wstąpienia do Kolegium, na co odpowiedział, że chce służyć Bogu i przygotować się do przyjęcia święceń kapłańskich ${ }^{11}$.

W momencie przyjazdu Agopsowicza do Kolegium rektorem był ks. Sarkis Der Abrahamian, natomiast w kolejnym roku funkcję tę objął ks. Ghazaros Agadżanian - późniejszy patriarcha Kościoła ormiańskokatolickiego Krikor Bedros XV i kardyna ${ }^{12}$. Po odbyciu kursu przygotowawczego Agopsowicz rozpoczął w roku akademickim 1932/1933 studia na Uniwersytecie Gregoriańskim. Trzy lata uczęszczał na zajęcia z filozofii, a od roku akademickiego 1935/1936

8 Sprawozdanie Dyrekcji I Gimnazjum Państwowego im. Mieczysława Romanowskiego w Stanisławowie za rok szkolny 1930/1931, Stanisławów 1931, s. 47.

9 W „Posłańcu św. Grzegorza” zamieszczono informacje, że klerycy wyjechali ze Lwowa do Rzymu na początku sierpnia 1931 roku. T. Krzyżow ski, Archidiecezja lwowska obrządku ormiańskokatolickiego w latach 1902-1938, Kraków 2020, s. 293.

10 Ibidem, s. 290, 295.

${ }^{11}$ Congregazione per le Chiese Orientali. Archivio Storico (dalej: CChO) w Watykanie: sygn. 514/31, k. 1, Domande cui dovranno i postulanti prima di ricevere il permesso della loro ammissione al Pontificio Collegio Leoniano istituto in Roma per gli Armeni, Joannes Joseph Agopsovich de Hasso, Roma 1931.

12 T. Krzyżowski, Archidiecezja lwowska, s. 298. 
na wykłady z teologii, historii Kościoła i prawa kanonicznego ${ }^{13}$. W 1934 roku przyjął tonsurę. Gdy w połowie października tegoż roku do Rzymu dotarła informacja o śmiertelnej chorobie jego matki, która przeszła operację żołądka i pragnęła spotkać się z synem, wyjechał za zgodą kardynała Luigiego Sincero, sekretarza Kongregacji dla Kościołów Wschodnich do Polski. Wrócił 7 listopada $^{14}$, a w kilka dni później, 13 listopada, matka zmarła. Na pogrzeb już nie mógł pojechać ${ }^{15}$. W 1935 roku otrzymał cztery święcenia niższe ${ }^{16}$. Formacja $\mathrm{w}$ kolegium ormiańskim i studia uniwersyteckie dawały solidne wykształcenie z zakresu filozofii i teologii, umiejętności językowe oraz umożliwiały nawiązanie znajomości z duchownymi ormiański-

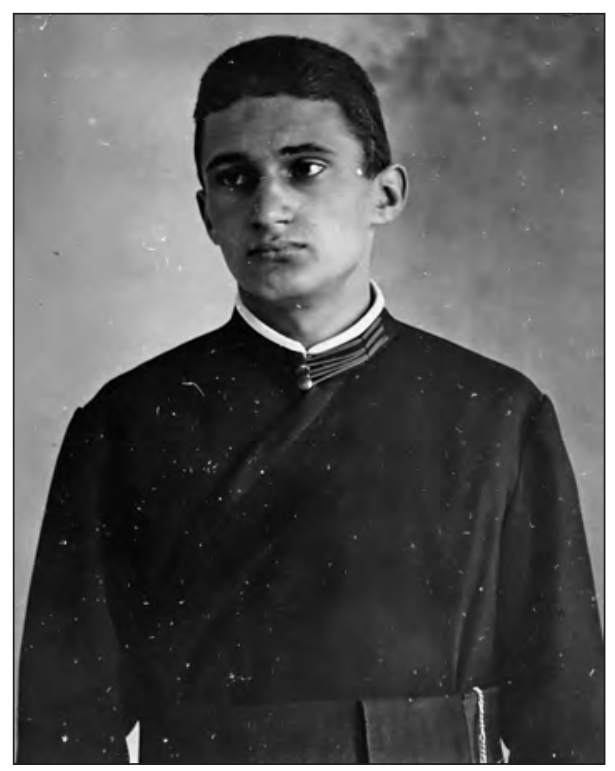

2. Jan Hasso Agopsowicz - alumn Papieskiego Kolegium Ormiańskiego w Rzymie, Rzym, około 1935, Zbiory Fundacji Kultury i Dziedzictwa Ormian Polskich w Warszawie $\mathrm{mi} \mathrm{z}$ różnych części świata ${ }^{17}$. Klerycy ze Lwowa utrzymywali stały kontakt korespondencyjny $\mathrm{z}$ arcybiskupem Józefem Teodorowiczem, który odwiedzał Kolegium podczas wizyt w Wiecznym Mieście ${ }^{18}$.

Jan Agopsowicz przebywał w Papieskim Kolegium Ormiańskim do jesieni 1938 roku. Wówczas zrezygnował z finalizacji studiów teologicznych w Rzymie, wrócił do Polski i zamieszkał we Lwowie. Prawdopodobnie do takiej decyzji przyczynił się stan jego zdrowia, gdyż upalny klimat i kuchnia włoska mu nie

${ }_{13}$ Schematismus archidioecesis Leopoliensis ritus armeno-catholici pro Anno Domini 1932-1933, 1935-1936, Leopoli 1932-1933, 1935-1936, passim.

${ }^{14}$ CChO: sygn. 514/31, k. 2, pismo G. Agadżaniana do kard. L. Sincero, Rzym 15 października 1934; k. 4, brudnopis pisma Kongregacji dla Kościołów Wschodnich do G. Agadżaniana, Rzym 18 października 1934; k. 5, pismo G. Agadżaniana do kard. L. Sincero, Rzym, 7 listopada 1934.

15 Relacja Anny Agopsowicz Paczki, Kraków, 15 lutego 2021 roku.

${ }^{16}$ CChO: sygn. 514/31, k. 6, notatka informująca o przyjęciu święceń niższych przez Jana Hasso Agopsowicza, Rzym 16 października 1935.

17 T. Krzyżowski, Archidiecezja lwowska, s. 299.

${ }^{18}$ Archiwum Fundacji Kultury i Dziedzictwa Ormian Polskich (dalej: AFKiDOP) w Warszawie: Spuścizna arcybiskupa Józefa Teodorowicza, sygn. 552, s. 1-3, list Jana Agopsowicza, Kazimierza Roszki i Grzegorza Petrowicza do arcybiskupa Józefa Teodorowicza, Rzym, 14 maja 1937. 
odpowiadały i nasilały problemy zdrowotne. Szczególnie we znaki dawały się mu wrzody żołądka, z którymi zmagał się od wielu lat ${ }^{19}$.

W życiorysach zawodowych z okresu powojennego Agopsowicz pomijał informacje o studiach filozoficzno-teologicznych oraz pobycie w Papieskim Kolegium Ormiańskim, co, biorąc pod uwagę ówczesny system polityczny w Polsce, jest zrozumiałe. Odnośnie do swojego wykształcenia uniwersyteckiego podawał natomiast informacje dość zaskakujące. Mianowicie, że w latach 1932-1935 studiował biologię na Wydziale Filozoficznym Uniwersytetu Gregoriańskiego w Rzymie, a potem chemię na Uniwersytecie Padewskim, które miał ukończyć w 1937 roku. W kwestionariuszu osobowym napisał też, że posiada doktorat z biologii i magisterium z chemii, czego nie potwierdzają inne źródła ${ }^{20}$. W Rzymie miał też w latach 1937-1938 rozpocząc praktykę zawodową, podejmując pracę w dwóch laboratoriach medycznych i ,poświęcając się z zamiłowaniem chemii klinicznej i hematologii" "21. Powyższe informacje poparł odpisami dyplomów wspomnianych uczelni. Zagadkowe pozostaje jednak, jak zdobył wykształcenie w dziedzinie biologii i chemii, skoro w tym samym czasie studiował filozofię i teologię oraz odbywał formację jako alumn seminarium duchownego?

\section{Praca zawodowa w laboratoriach analitycznych}

Do Lwowa Agopsowicz przyjechał w październiku 1938 roku i zamieszkał w domu arcybiskupów ormiańskich. Jego sąsiadką była tam Maria Kapri - sekretarka arcybiskupa Teodorowicza ${ }^{22}$. W życiorysie spisanym w okresie PRL, gdy nie było rozsądnym informować pracodawcę o studiach teologicznych, podał, że po powrocie do Polski ciężko chorował ${ }^{23}$. Natomiast w schematyzmie archidiecezji lwowskiej obrządku ormiańskiego z 1939 roku czytamy, że Jan Agopsowicz był klerykiem piątego roku i studiował w studium teologicznym prowadzonym przez lwowskich bernardynów ${ }^{24}$.

19 Archiwum Szpitala Specjalistycznego im. Jędrzeja Śniadeckiego w Nowym Sączu (dalej: ASNS): życiorys Jana Agopsowicza, Nowy Sącz, 1960; odpis uwierzytelniony dyplomu Uniwersytetu Gregoriańskiego, Rzym, 1955.

${ }^{20}$ ASNS: życiorys Jana Agopsowicza, Nowy Sącz, 1960; kwestionariusz osobowy Jana Agopsowicza, Nowy Sącz, 1960; odpis uwierzytelniony dyplomu Uniwersytetu Gregoriańskiego, Rzym, 1955; odpis uwierzytelniony dyplomu Uniwersytetu Padewskiego, Lwów, 1939. Informacje o doktoracie z biologii i magisterium z chemii zawiera także publikacja: J. Leśniak, A. Leśniak, Agopsowicz-Hasso Jan, w: Encyklopedia sądecka, Nowy Sącz 2000, s. 10.

${ }^{21}$ ASNS: życiorys Jana Agopsowicza, Nowy Sącz, 1960.

22 Relacja Barbary Agopsowicz Krasowskiej, Kraków, 4 marca 2021 roku.

23 ASNS: życiorys Jana Agopsowicza, Nowy Sącz, 1960.

${ }^{24}$ Schematismus archidioecesis Leopoliensis ritus armeno-catholici pro Anno Domini 1939, Leopoli 1939, s. 36. Kwerenda w aktach wspomnianego studium, przechowywanych w Archiwum Prowincji oo. Bernardynów w Krakowie, nie potwierdza tej informacji. 
Po wybuchu drugiej wojny światowej i wejściu wojsk sowieckich do Lwowa Agopsowicz zaangażował się $\mathrm{w}$ akcję pomocy przy nielegalnych wyjazdach do Rumunii przez granicę w Kutach, zorganizowaną przez księży pracujących przy katedrze ormiańskiej dla osób zagrożonych przez okupanta ${ }^{25}$. $\mathrm{W}$ tym czasie zrezygnował ostatecznie z obranej wcześniej drogi życiowej i 29 września 1940 roku w katedrze ormiańskiej zawarł związek małżeński z lwowianką Emilią Walków (1917-1998) ${ }^{26}$. Zatrudnił się $\mathrm{w}$ prowadzonym przez dr. Jana Dąbrowskiego przy ul. Ormiańskiej 7 we Lwowie laboratorium analiz lekarskich, które działało od lutego 1941 roku, a więc pod koniec okupacji sowieckiej Lwowa i przez cały czas okupacji niemieckiej. Po zniszczeniu pracowni w maju 1944 roku i zmianie granic Polski zdecydował się na wyjazd ze Lwowa. Osiadł w Kamiennej Górze, gdzie od czerwca 1945 do czerwca 1946

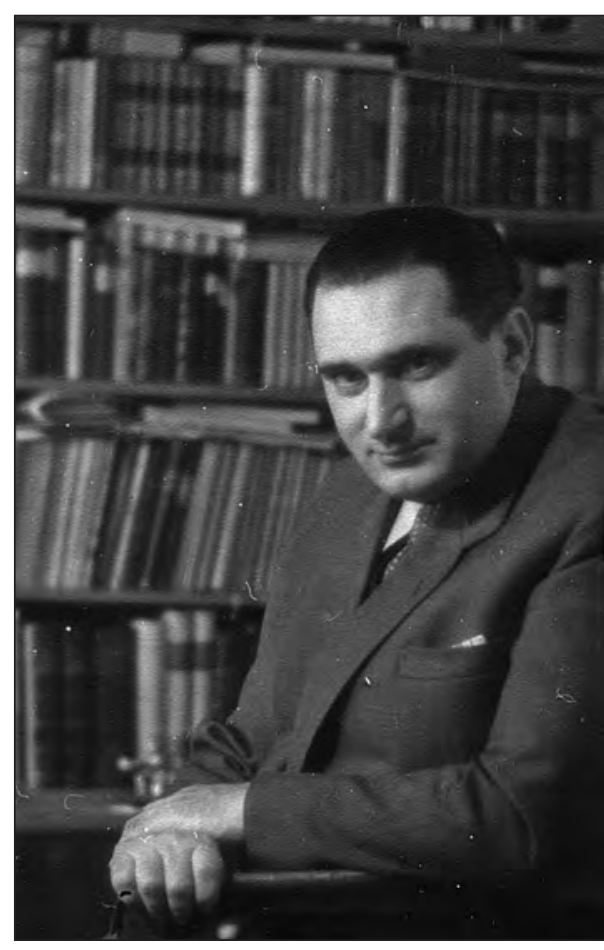

3. Jan Hasso Agopsowicz w swoim mieszkaniu w Nowym Sączu, lata 50. XX wieku, Zbiory Fundacji Kultury i Dziedzictwa Ormian Polskich w Warszawie roku pracował w Laboratorium Wydziału Zdrowia ${ }^{27}$. Następnie na krótko zamieszkał z żoną i córką w Starym Sączu, dokąd po ekspatriacji ze Lwowa udała się rodzina żony. W czerwcu 1947 roku otrzymał przydział mieszkania o powierzchni około 100 metrów kwadratowych w Nowym Sączu przy ul. Jagiellońskiej $72^{28}$, w kamienicy zbudowanej w 1936 roku $^{29}$. W tym czasie rozpoczął pracę w laboratorium prowadzonym przez dr Marynowską w Nowym Sączu (do lipca 1948 roku), a we wrześniu 1948 roku zorganizował pracownię analityczną Ubezpieczalni Społecznej ${ }^{30}$. W tym

25 T. Dubicki, Konspiracja polska w Rumunii 1939-1945, 1, Warszawa 2002, s. 98.

${ }^{26} \mathrm{Z}$ małżeństwa tego urodziły się dwie córki: Barbara (1946), zamężna Krasowska, i Anna (1951), zamężna Paczka (ZBAK: J. Has so Agopsowicz, Genealogia, s. 66).

27 ASNS: kwestionariusz osobowy Jana Agopsowicza, Nowy Sącz, 1960; życiorys Jana Agopsowicza, Nowy Sącz, 1960.

${ }^{28}$ Relacja Anny Agopsowicz Paczki, Kraków, 15 lutego 2021 roku.

${ }^{29}$ L. Migrała, Ulica Jagiellońska w Nowym Sączu od końca XIX wieku do 1945 roku mieszkańcy i zabudowa, Nowy Sącz 2012, s. 120.

${ }^{30}$ Przebieg pracy zawodowej Jana Agopsowicza nieznacznie różni się w kwestionariuszu oraz w życiorysie. W pierwszym z wymienionych dokumentów podaje, że ze Lwowa udał się 
samym roku rozpoczął pracę w laboratorium analitycznym w Szpitalu Powszechnym w Nowym Sączu ${ }^{31}$, którego został kierownikiem. Dla dyrekcji i personelu placówki był to trudny okres zmagań o rozbudowę szpitala, usprawniania jego działalności oraz nadrabiania czasu stagnacji spowodowanego wojną ${ }^{32}$. Agopsowicz uzupełnił swoje wykształcenie medyczne w Państwowej Szkole Laborantów Medycznych w Gliwicach ${ }^{33}$. W latach 60 . dostał dodatkowy angaż w laboratorium Miejskiej Przychodni Obwodowej w Nowym Sączu ${ }^{34}$. Prowadził również zajęcia z bakteriologii w Państwowej Szkole Pielęgniarstwa w Nowym Sączu ${ }^{35}$. W szpitalnym laboratorium Agopsowicz przepracował prawie trzydzieści lat, w 1976 roku przeszedł na emeryturę. W korespondencji ze znajomymi przyznał, że praca była ciężka i stresująca ${ }^{36}$.

\section{Zagraniczne podróże (Włochy, Armenia, Ukraina)}

W 1962 roku Agopsowicz złożył wniosek paszportowy w celu wyjazdu turystycznego do Włoch na zaproszenie przyjaciela, Jana (Giovanniego) Chabaniana, Ormianina mieszkającego w Rzymie. Pojechał samochodem z żoną oraz znajomymi ${ }^{37}$. Oprócz wypoczynku i zwiedzania Wiecznego Miasta spotkał się z kard. Agadżanianem (o czym będzie jeszcze mowa dalej). W Rzymie bywał także w późniejszych latach; zatrzymywał się zawsze w Papieskim Kolegium Ormiańskim w pokojach gościnnych na najwyższym piętrze ${ }^{38}$.

Agopsowicz marzył o podróży do Armenii, kraju przodków, z którym był mocno związany. W 1968 roku na zaproszenie Stanisława Pawłowicza, który

do Kamiennej Góry, a w drugim, że do Starego Sącza i nie wspomina o pracy w Kamiennej Górze. Zastanawiające są również przerwy w jego angażach. Agopsowicz nie podaje miejsca pobytu i pracy od czerwca 1944 roku do czerwca 1945 roku oraz od czerwca 1946 roku do czerwca 1947 roku. ASNS: życiorys Jana Agopsowicza, Nowy Sącz, 1960; kwestionariusz osobowy Jana Agopsowicza, Nowy Sącz, 1960.

31 Od 1949 roku - Szpital Miejski, od 1953 roku - im. Jędrzeja Śniadeckiego.

32 ASNS: życiorys Jana Agopsowicza, Nowy Sącz, 1960; M. J. Nowak, Z. Mordawski, Opieka zdrowotna i opieka społeczna w latach 1945-1990, w: Dzieje miasta Nowego Sacza, 3, red. F. Kiryk, Z. Ruta, Kraków 1996, s. 785.

33 ASNS: pismo Prezydium Wojewódzkiej Rady Narodowej w Krakowie do Prezydium Powiatowej Rady Narodowej w Nowym Sączu, Kraków, 27 grudnia 1963.

${ }^{34}$ ASNS: pismo kierownika Miejskiej Przychodni Obwodowej do J. Agopsowicza, Nowy Sącz, 15 lutego 1961.

35 ASNS: pismo dyrekcji Państwowej Szkoły Pielęgniarstwa do kierownika Przychodni Obwodowej w Nowym Sączu, Nowy Sącz, 12 września 1960.

${ }^{36}$ Archiwum Prowincji Franciszkanów Reformatów w Krakowie (dalej: APFRK): list J. Agopsowicza do o. Jana Modesta Pasiecznika, Nowy Sącz, 10 stycznia 1976.

37 Archiwum Instytutu Pamięci Narodowej, Oddział w Krakowie: sygn. 39/23658, s. 15 17, podanie Jana Agopsowicza do Biura Paszportów, Nowy Sącz, 18 kwietnia 1962.

38 Relacja Barbary Agopsowicz Krasowskiej, Kraków, 4 marca 2021. 
mieszkał w Erywaniu, udał się wraz z córką Barbarą na trzytygodniową wyprawę do Armenii. Zwiedził Eczmiadzyn i Matenadaran, był w Bibliotece Narodowej i nad jeziorem Sewan. Wizyta stanowiła okazję do wielu rozmów oraz nawiązania nowych znajomości. Spotkał się m.in. ze znanym malarzem Aszotem Mamadżanianem oraz dyrektorem Biblioteki im. Aleksandra Miasnikiana w Erywaniu, Spartakiem Ghazarianem. Nie zdołał jednak dotrzeć do wszystkich interesujących go miejsc, zwłaszcza zabytków znajdujących się w górach, z powodu problemów zdrowotnych, nasilających się w upalnym klimacie ${ }^{39}$.

W sierpniu 1973 roku Agopsowicz wraz z żoną udał się do Lwowa i Stanisławowa. Rodzinne strony planował odwiedzić od dawna, ale nie mógł uzyskać zaproszenia, dlatego skorzystał z oferty biura podróży „Orbis”. Kilka dni spędzili we Lwowie, gdzie mieszkali w hotelu „Lviv” usytuowanym tuż obok opery. Podróż po sowieckiej Ukrainie Agopsowicz relacjonował w liście do ks. Kazimierza Filipiaka, którego fragmenty warto przytoczyć:

Pierwsze nasze kroki skierowaliśmy do naszej katedry. Trudno opisać, jak wygląda Lwów, to trzeba zobaczyć. Na nas zrobił wrażenie szarego biednego miasta. Ulice jak były zniszczone przez działania wojenne, tak pozostały do dnia dzisiejszego. [...] Nasz zaułek ormiański ogromnie zniszczony, w rozsypce! Katedra, z zewnątrz w możliwym stanie, jest stale zamknięta, gdyż jest składem obrazów zebranych z innych kościołów. Pałac biskupów podzielony na szereg małych, jednopokojowych mieszkań. [...] Mimo zakazu pojechaliśmy okazją do Stanisławowa. Od razu zajechaliśmy na rynek. Kościół nasz odsłonięty przez zburzenie kamienic zasłaniających go od rynku stoi w dobrym stanie bez obrazu M[atki] B[ożej] i z obciętymi krzyżami. Ulica przed kościołem i plebanią nazywa się Jerewańska. Przy drzwiach kościelnych tablica z napisem: Muzeum religioznawstwa i ateizmu. Dzięki temu jest zachowany $b$ [ardzo] dobrze. Malowidła ścienne i figury zachowane. Główny ołtarz zasłonięty niebieską szmatą, a przed nim stoi model sputnika. Wokół fotografie o pochodzeniu człowieka oraz popiersia Marksów, Engelsów etc. Zrobiłem kilka zdjęć, które przesyłam w załączeniu. Byłem jeszcze w domu, gdzie mieści się oddział kliniki dziecięcej (ul. Moniuszki), a potem pojechaliśmy na cmentarz do moich rodziców. Długi czas błądziliśmy, ponieważ kościół niemiecki, który znajdował się przy alei prowadzącej na cmentarz, nie istnieje, a aleja i główne wejście na cmentarz [są] zabudowane blokami. Wreszcie dojechaliśmy na cmentarz jakoś z boku. Przez godzinę z płaczem szukałem grobowca rodziców i nie mogłem znaleźć. Cmentarz wygląda jak busz afrykański, zarośnięty burzanami. Niektóre grobowce, uszkodzone i otwarte, nawet na sowiecie, który nas przywiózł, robiły straszne wrażenie. Wreszcie jakiś sowiet, który z Nowosybirska przyje-

39 Ibidem. 
chał na grób ojca swego, pokazał mi, gdzie była główna brama, wtedy już trafiłem do rodziców. Oczyściliśmy grobowiec, zapaliliśmy świeczki, popłakali, i pojechaliśmy z powrotem do Lwowa, nie chcąc kręcić się niepotrzebnie i wpadać w oczy milicji ${ }^{40}$.

\section{Troska o środowisko Ormian polskich i zachowanie obrządku ormiańskiego}

Z zachowanej korespondencji Agopsowicza, kierowanej do znajomych Ormian, wynika, że dużą wagę przywiązywał do losów diaspory ormiańskiej w Polsce oraz śledził jej aktualną sytuację. W okresie powojennym nie istniała w Polsce żadna organizacja świecka zrzeszająca Ormian, dlatego możliwości ich konsolidacji były mocno ograniczone. Ekspatriowani z Kresów po drugiej wojnie światowej, rozproszyli się na terenie całej Polski. Jedyną okazją do spotkań w większym gronie były nabożeństwa w obrządku ormiańskim odprawiane nieregularnie w kilku miastach w Polsce. W korespondencji Agopsowicz używał sformułowania „mały światek ormiański”. Miał świadomość, że epoka związana z Kresami bezpowrotnie się zakończyła, a powojenne okoliczności nie sprzyjają integracji środowiska ${ }^{41}$. Bardzo zależało mu na zapewnieniu Ormianom polskim opieki duszpasterskiej oraz możliwości funkcjonowania ormiańskich parafii katolickich. Tymczasem sytuację komplikował nieuregulowany status prawny obrządku ormiańskiego w Polsce. Żyło jeszcze zaledwie kilku starszych wiekiem duszpasterzy, a nowych powołań kapłańskich brakowało.

Wszystkie sprawy organizacyjne dotyczące obrządków wschodnich Stolica Apostolska powierzyła kard. Stefanowi Wyszyńskiemu, prymasowi Polski ${ }^{42}$. Uważał on, że Ormian jest już bardzo mało, są rozproszeni i mają zapewnioną opiekę duchową kapłanów rzymskokatolickich. Dlatego był przeciwny pielęgnowaniu tradycji ich własnego obrządku ${ }^{43}$. Agopsowicz zastanawiał się, jakie kroki podjąć, aby Kościół ormiańskokatolicki w Polsce mógł się nadal rozwijać. Uważał, że najlepszym rozwiązaniem byłoby powołanie przez Stolicę Apostolską administratora apostolskiego dla Ormian katolików, który miałby szerokie kompetencje w kwestiach organizacyjnych i duszpasterskich.

${ }^{40}$ AFKiDOP, list J. Agopsowicza do ks. K. Filipiaka, Nowy Sącz, 20 września 1973.

${ }^{41}$ APFRK, list J. Agopsowicza do o. J. M. Pasiecznika, Nowy Sącz, 10 stycznia 1976.

${ }^{42}$ Szerzej na temat dziejów obrządku ormiańskiego w Polsce po drugiej wojnie światowej zob. M. Białkow ski, Prymas Stefan Wyszyński jako ordynariusz wiernych obrzadku ormiańskiego. Szkic do dziejów religijnych diaspory Ormian polskich w latach 1957-1981, „Studia Gdańskie", 45, 2019, s. 149-171.

${ }^{43}$ AFKiDOP: Archiwum Jakubowiczów (dalej: AJ), sygn. 79, list J. Agopsowicza do A. Jakubowicza, Nowy Sącz, 21 lipca 1978. 
Zagadnienia związane z funkcjonowaniem Kościoła ormiańskiego w Polsce Agopsowicz wielokrotnie omawiał z ks. Grzegorzem Petrowiczem z Rzymu i zachęcał go do lobbowania w dykasteriach watykańskich na rzecz sprawy Ormian katolików w Polsce. Gdy w 1962 roku był w Rzymie, podjął interwencję osobiście. Wykorzystał dawne znajomości z kard. Agadżanianem, który od niedawna pełnił funkcję prefekta Kongregacji ds. Ewangelizacji Narodów (19601970). Fakt osobistej znajomości z watykańskim hierarchą umożliwił uzyskanie audiencji. Kardynał odniósł się życzliwie do postulatów Agopsowicza i miał mu powiedzieć: „Szkoda, że nie jesteś kapłanem, ciebie zrobiłbym od razu biskupem". Z kardynałem Agopsowicz utrzymywał kontakt korespondencyjny także w późniejszych latach i nadal uzyskiwał od niego deklaracje pomocy. Nazwał on Agopsowicza „ambasadorem” spraw Kościoła ormiańskiego w Polsce, zalecał częste wizyty w Wiecznym Mieście, których koszty proponował pokryć. Agopsowicz nie chciał nadużywać tej uprzejmości, czego później żałował.

Życzliwie nastawiony Agadżanian, posiadający wiedzę o sytuacji w Polsce z pierwszej ręki, tj. od Agopsowicza, podjął starania w Kongregacji dla Kościołów Wschodnich o mianowanie administratora apostolskiego dla wiernych obrządku ormiańskiego w Polsce. W listopadzie 1962 roku Kongregacja wyraziła na to zgodę. Administratorem miał zostać o. Stefan Moysa-Rosochacki, jezuita z Warszawy, pochodzący z ziemiańskiej rodziny ormiańskiej, która w Galicji za panowania Austrii otrzymała tytuł baronowski. W tym celu o. Moysa-Rosochacki powinien był opuścić zakon i zmienić obrządek na ormiański. Takiego rozwiązania nie zaaprobował kard. Wyszyński, a sam o. Moysa-Rosochacki napisał do Agopsowicza list pełen pretensji, oznajmiając, że od dziecka należał do obrządku rzymskokatolickiego, że nie uważa się za Ormianina i z Ormianami nie chce mieć nic wspólnego. Sprzeciw kard. Wyszyńskiego wobec projektu utworzenia odrębnej kościelnej jednostki administracyjnej dla ormiańskich katolików w Polsce zablokował jakiekolwiek dalsze działania w tej sprawie, gdyż kard. Agadżanian nie chciał ingerować w jego decyzje. Agopsowicz postanowił wyjaśnić sprawę i poznać motywy, jakimi kierował się prymas, dlatego spotkał się z jego sekretarzem, ks. Władysławem Padaczem. Ten oznajmił, że Ormianie mają w Polsce administratora, ale nie potrafił podać jego personaliów. Między rozmówcami doszło do ostrej wymiany zdań, tak że rozeszli się w niemiłej atmosferze. Agopsowicz uważał, że „od tego czasu kard. Wyszyński zupełnie jawnie okazuje nam swoją wrogość i dąży do zlikwidowania naszego obrządku w Polsce"44, a Kongregacja dla Kościołów Wschodnich odnosi się do sprawy z rezerwą ${ }^{45}$.

${ }^{44}$ Ibidem.

45 Ibidem, Spuścizna Stanisława Donigiewicza (dalej: SSD): sygn. 125, s. 1, list J. Agopsowicza do S. Donigiewicza, Nowy Sącz, 28 marca 1977. 


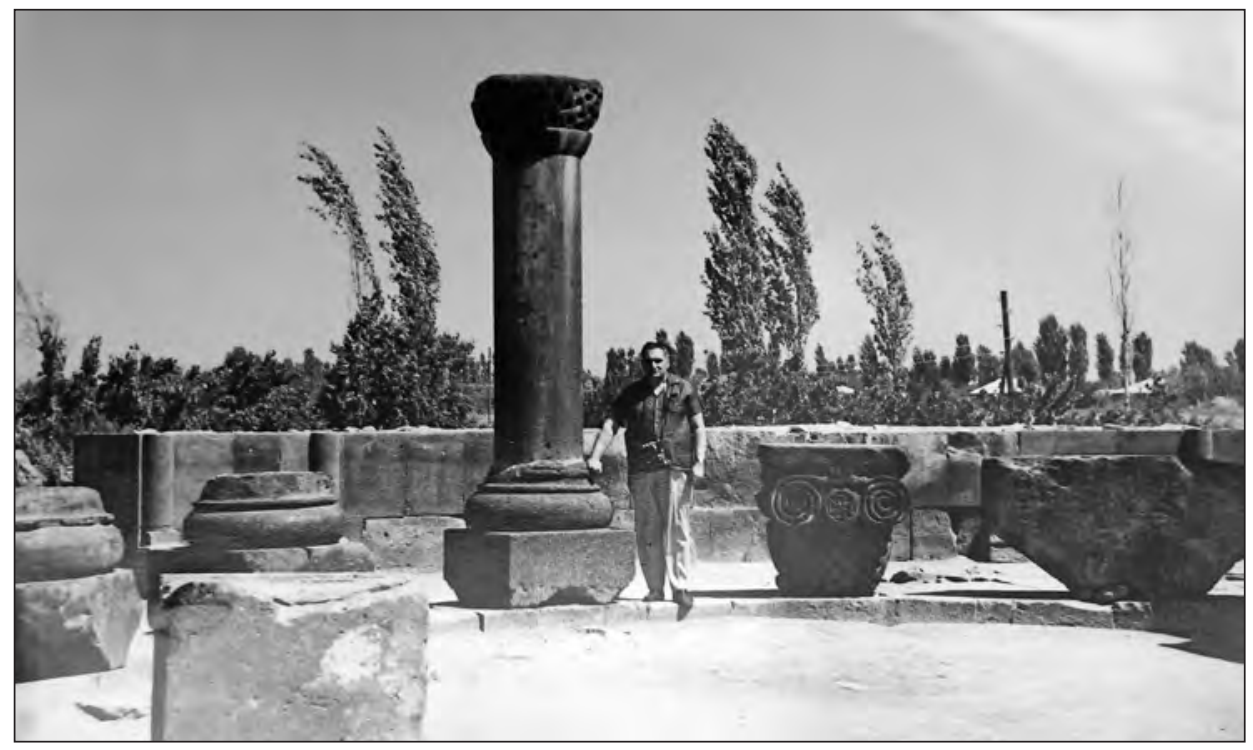

4. Jan Hasso Agopsowicz na wycieczce w Armenii, Zwartnoc, 1968, Zbiory Barbary Agopsowicz Krasowskiej w Krakowie

Nie udało się ustalić, czy w kolejnych latach Agopsowicz interweniował w Stolicy Apostolskiej w sprawie powołania administratora. Wiadomo, że temat ten omawiał z rektorem Papieskiego Kolegium Ormiańskiego, ks. Nersesem Setianem, ale rezultat rozmów pozostaje nieznany ${ }^{46}$. W 1971 roku zmarł kard. Agadżanian, co z pewnością utrudniło Agopsowiczowi kontakt z urzędami watykańskimi. W listach do Stanisława Donigiewicza z żalem konkludował:

Nie raz myślę sobie, jak strasznie doświadczył nas los podczas ostatniej wojny, jak wszystkie sprawy Ormian polskich zmierzają nieuchronnie ku zagładzie, jak przepada majątek kościelny i inne relikty kultury ormiańskiej i jak ogromnie trudno coś zrobić pozytywnego dla sprawy ormiańskiej! Jakieś przekleństwo na nas ciąży!47 [...] Osobiście mam wrażenie, że rzeczywiście kończy się wraz z nami nasz prastary obrządek i nie ma wyjścia $z$ tej całej sytuacji ${ }^{48}$.

Były to mocne i cierpkie słowa, wyrażające troskę i zawód po wieloletnich staraniach na rzecz unormowania sytuacji prawnej Kościoła ormiańskiego

${ }^{46}$ Ibidem, AJ, sygn. 79, list J. Agopsowicza do A. Jakubowicza, Nowy Sącz, 21 lipca 1978.

${ }^{47}$ Ibidem, SSD, sygn. 125, s. 2, list J. Agopsowicza do S. Donigiewicza, Nowy Sącz, 28 marca 1977.

48 Ibidem, sygn. 52, s. 5, list tegoż do tegoż, Nowy Sącz, 8 maja 1980. 
w Polsce. Agopsowicz pozytywnie oceniał rolę Stolicy Apostolskiej i postawę kard. Agadżaniana, winą obarczał księży ormiańskich pracujących w Polsce. Tak to wyłożył w liście do Marii Kapri, zwracając przy okazji uwagę na jeszcze jeden ważny czynnik porażki swych starań - negatywne stanowisko władz komunistycznych:

Sprawa naszego obrządku to bardzo bolesna dla mnie sprawa. Trudno obecnie coś zdziałać, kiedy od końca wojny nic w tym kierunku nie zdziałano. Nie było nigdy zgody wśród naszych księży, z których każdy żył własnym życiem, nie znosząc nad sobą żadnej władzy. Gdyby się byli zorganizowali i utworzyli coś $\mathrm{w}$ rodzaju namiastki dawnej diecezji, bylibyśmy liczyli się nie tylko w administracji kościelnej, ale również w urzędzie do spraw wyznań, który teraz uważa obrządek ormiański za niepotrzebny i definitywnie zlikwidowany. [...] Nic nie pomogły moje interwencje, bo, prawdę mówiąc, sami księża ormiańscy pogrzebali swój obrządek $^{49}$.

Aktywność diaspory ormiańskiej w Polsce zintensyfikowała się w latach 80. XX wieku. W Krakowie 24 marca 1980 roku powstało Koło Zainteresowań Kulturą Ormian przy Polskim Towarzystwie Ludoznawczym. W ramach jego działalności w listopadzie 1980 roku zorganizowano sesję naukową, która stała się pretekstem do spotkania środowiska ormiańskiego w Polsce ${ }^{50}$. Uczestniczył w niej Jan Agopsowicz, do czego zachęcał go jeden z organizatorów, dr Janusz Kamocki, oraz duszpasterz Ormian polskich, ks. Kazimierz Filipiak ${ }^{51}$. O tym przełomowym wydarzeniu pisał potem:

Przeżyliśmy ten ewenement bardzo głęboko. Spotkaliśmy różnych przyjaciół i znajomych, których nie widzieliśmy od prawie 40-tu lat. Dr Kamocki, przezacny człowiek, zasłużył się wielce dla sprawy ormiańskiej, ale nie dało się, ze zrozumiałych względów, restytuować dawnego Związku Ormian we Lwowie. Musieliśmy skorzystać z okazji i stać się oddziałem Towarzystwa Ludoznawczego. Może jednak coś z tego wyjdzie. Dzięki temu stowarzyszeniu miłośników kultury ormiańskiej Ormianie, rozsiani po Polsce, odszukali się wzajemnie i postanowili zjednoczyć się ${ }^{52}$.

49 AFKiDOP, kopia listu J. Agopsowicza do M. Kapri, Nowy Sącz, 22 stycznia 1979; Por. też: AFKiDOP: AJ, sygn. 79, list J. Agopsowicza do A. Jakubowicza, Nowy Sącz, 21 lipca 1978.

${ }^{50}$ G. Pełczyński, Ormianie polscy w XX wieku. Problem odrębności etnicznej, Warszawa 1997, s. $85,87$.

${ }^{51}$ AFKiDOP: SSD, sygn. 52, s. 22, list J. Agopsowicza do S. Donigiewicza, Nowy Sącz, 25 sierpnia 1980.

52 APFRK, list J. Agopsowicza do o. J. M. Pasiecznika, Nowy Sącz, 15 kwietnia 1981. 
W tym kontekście zaznaczyć należy, że Jan Agopsowicz pielęgnował ormiańskie tradycje wyniesione $\mathrm{z}$ domu rodzinnego, m.in. przygotowywał zupę chorutową (tzw. gandżabur) oraz tradycyjne ciasto ${ }^{53}$.

\section{Bibliofil i ekslibrisofil}

Wielką pasją Agopsowicza było kolekcjonowanie i projektowanie ekslibrisów. Być może genezę jego zainteresowań sztuką oraz wrażliwość na piękno i estetykę wiązać należy ze studiami w Rzymie, obfitującym w zabytki i dzieła sztuki ${ }^{54}$. Na rozwój jego zainteresowań w tym kierunku wypłynęła znajomość z lwowskim historykiem sztuki i muzeologiem Rudolfem Mękickim (1887-1942), znanym również z tworzenia ekslibrisów, oraz Tadeuszem Solskim (1884-1966), kolekcjonerem i bibliofilem ${ }^{55}$. W 1942 roku Mękicki wykonał dla Agopsowicza trzy ekslibrisy $\mathrm{w}$ technice cynkotypii barwnej. Pierwszy $-\mathrm{z}$ napisem literami polskimi stylizowanymi na ormiańskie, pod którym umieścił herb Hasso, przedstawiający gołębia $\mathrm{z}$ gałązką $\mathrm{w}$ dziobie, a $\mathrm{z}$ prawej strony ornament roślinny. Drugi ekslibris miał podobną kompozycję i zdobienia oraz napis w języku ormiańskim: „Z książek Jana Hasso Agopsowicza we Lwowie”. Trzeci ekslibris przedstawiał katedrę ormiańską we Lwowie od strony wschodniej, ozdobioną kolorowymi ornamentami oraz napisem w języku polskim literami stylizowanymi na ormiańskie ${ }^{56}$. Przypuszczalnie to właśnie działalność artystyczna Mękickiego zainspirowała Agopsowicza do własnej pracy twórczej.

Pierwszy ekslibris wykonał dla siebie w 1943 roku. Był to szkic katedry ormiańskiej ujętej w arkadę ozdobioną motywami florystycznymi i ptakami oraz stylizowanym napisem umieszczonym na dole kompozycji. Kolejny, z 1944 roku, zaprojektował w kształcie gotyckiej owalnej pieczęci z rodowym herbem przedstawiającym gołębia z gałązką w dziobie, oplecionym wężem trzymającym w pysku ogon, zwieńczonym koroną oraz otoczonym stylizowanym napisem w języku łacińskim. Kolejne trzy autoekslibrisy wykonał w latach powojennych. W 1961 roku dwa z herbem Hasso oraz w 1976 roku z postacią św. Mateusza, zaczerpniętą z XIII-wiecznego ewangeliarza ormiańskiego, z napi-

53 AFKiDOP: SSD, sygn. 52, s. 17, list J. Agopsowicza do S. Donigiewicza, Nowy Sącz,

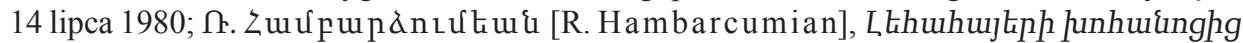

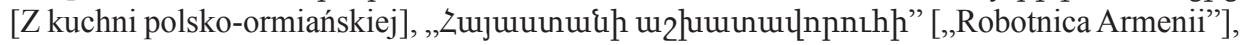
1979, 2, s. 30-31.

${ }_{54}$ T. T. Gudzowski, Ormiańskie ekslibrisy Jana Agopsowicza, „Dunajec”, 8, 1987, 50, s. 8-9.

55 Ibidem; Archiwum Państwowe w Przemyślu: sygn. 108, k. 1, list J. Agopsowicza do M. Słowika, Nowy Sącz, 21 września 1968; M. Grońska, Ekslibrisy. Wiadomości zebrane dla kolekcjonerów, Warszawa 1992, s. 54.

${ }^{56}$ Mistrzowie ekslibrisu polskiego. Rudolf Mękicki, oprac. G. Korde1, [Warszawa 2019], s. 40,42 . 
sem $\mathrm{w}$ języku polskim i ormiańskim oraz rodowym herbem zwieńczonym koroną książęcą.

Agopsowicz tworzył ekslibrisy użytkowe, przeznaczone do oznaczenia książek. Artysta łączył prezentowane na grafice treści z profesją bądź zainteresowaniami bibliofila. W związku z tym ekslibris był nie tylko ozdobą książki, ale i „wizytówką osobowości właściciela" ${ }^{57}$. Agopsowicz podejmował w swojej twórczości bardzo różnorodną tematykę. Jego kompozycje nawiązywały do postaci bądź wydarzeń historycznych, zabytków, dokumentów pergaminowych, monet, ksiąg, pieczęci czy herbów. Pojawiały się także rośliny i zwierzęta, zwłaszcza lew, orzeł, gołąb, wąż. Artysta wprowadzał motywy naczyń i sprzętów oraz elementów architektonicznych starożytnej Grecji i Rzymu, ozdobnych napisów, postaci bóstw. Często nawiązywał do zabytków Lwowa. Dużą wagę przywiązywał do szczegółów, doboru czcionki i odpowiedniego papieru. Prace komponował w formie prostokąta, kwadratu, trójkąta, owalu, koła. Drukował przeważnie w kolorze czarnym, rzadziej w zieleni, brązie czy sepii ${ }^{58}$.

W okresie bez mała czterdziestoletniej aktywności artystycznej (1943-1982) Agopsowicz zaprojektował 239 ekslibrisów, w tym 38 nieukończonych ${ }^{59}$. Rozkwit twórczości przypada na drugą połowę lat 70 . XX wieku, po przejściu na emeryturę. W 1976 roku zaprojektował 38, w 1977 - 26, w 1978 - 18, w 1979 14, w 1980 - 19, łącznie z projektami nieukończonymi ${ }^{60}$. Ekslibrisy rysował tuszem do reprodukcji cynkotypowej ${ }^{61}$. Swoje prace sygnował inicjałami imienia i nazwiska, stosował też sygnatury obrazkowe w kilku wersjach ${ }^{62}$.

Warto przyjrzeć się bliżej ekslibrisom zawierającym motywy ormiańskie. Większość z nich została zaprojektowana dla znajomych Ormian. W 1958 roku Agopsowicz wykonał metodą hektografii ekslibris dla ormiańskiego księdza, Franciszka Jakubowicza z Krakowa. Umieścił na nim postać błogosławiącego Chrystusa, zaczerpniętą z ewangeliarza ormiańskiego z XIII wieku, i napis w języku staroormiańskim (grabarze). Dwa ekslibrisy zaprojektował dla swojego przyjaciela, Michała Bohosiewicza z Gliwic - z wykształcenia prawnika, z zamiłowania bibliofila i kolekcjonera armeniców, znawcę genealogii rodzin

57 Jan Hasso Agopsowicz. Ekslibrisy. Wystawa - Wroctaw 16-26 IX 1981, oprac. M. Mazurkiewicz, Wrocław 1981, b. pag.

${ }^{58}$ Ibidem; In memoriam Jana Hasso Agopsowicza, red. J. T. Czosnyka, Nowy Sącz 1982; R. Lew and ow ski, Exlibrisy Jana Hasso Agopsowicza, Lipno 1979, s. 3-6.

59 Pełny wykaz ekslibrisów Agopsowicza zob. Jan Hasso Agopsowicz. Ekslibrisy; T. Suma, Jan Hasso Agopsowicz (1915-1982). Spis kompletny, http://ekslibrispolski.pl/?page_ id=2636; (dostęp: 27 stycznia 2021). Zob. też: Jan Hasso Agopsowicz. Ekslibrisy, oprac. J. Drużycki, Nowy Sącz-Wrocław 1973.

${ }^{60}$ Jan Hasso Agopsowicz. Ekslibrisy.

${ }^{61}$ M. J. Wojciechowski, Ekslibris godło bibliofila, Wrocław 1978, s. 189.

${ }^{62}$ M. Grońska, Ekslibrisy, s. 84; T. Suma, Sygnatury polskich twórców ekslibrisów od XIX wieku do wspótczesności. Leksykon, Warszawa 2013, s. 35, 91. 
ormiańskich i heraldyki. Znaki nawiązywały do jego zainteresowań i zawierały motywy heraldyczne. Pierwszy z 1969 roku z herbem Sas i napisem w języku polskim i ormiańskim, drugi - z 1978 roku z herbem Bukowiny i herbem Sas, mapą Bukowiny i Pokucia oraz napisami polsko-ormiańskimi. Pozostałe trzy projekty dla Bohosiewicza, z 1975 roku, z motywami heraldycznymi nie zostały ukończone. Trzy projekty przygotował dla Stanisława Donigiewicza, zasłużonego działacza środowiska ormiańskiego w Polsce. Pierwszy z 1943 roku, trójbarwny, z motywami polsko-ormiańskimi, zaginął w czasie drugiej wojny światowej. Dwa powojenne projekty zostały zrealizowane i nawiązywały do zabytków ormiańskich we Lwowie: pierwszy z pasażem za katedrą ormiańską (1977), drugi z głową z portalu przy ul. Ormiańskiej oraz napisami w języku polskim i ormiańskim (1978). W 1976 roku zaprojektował ekslibris dla ks. Kazimierza Filipiaka, przedstawiający fasadę kościoła ormiańskiego w Stanisławowie ${ }^{63}$.

Zarówno zainteresowania Agopsowicza historią i kulturą ormiańską, jak i utrzymywanie licznych kontaktów z Ormianami zaowocowały powstaniem około dziesięciu ekslibrisów dedykowanych znajomym z Armenii. Dla Spartaka Ghazariana, bibliotekarza z Erywania, w roku 1977 zaprojektował ekslibris z motywem zaczerpniętym z ormiańskiego manuskryptu, z dwoma kogutami. Ekslibris Aszota Mamadżaniana z roku 1977, malarza i grafika, przedstawiał świątynię w Eczmiadzynie i górę Ararat. Dwa ekslibrisy wykonał dla Rafaela Hambarcumiana (1978), ormiańskiego historyka, autora prac o Ormianach polskich. Jeden przedstawiał detale z ornamentyki pulpitu z kościoła w Ani z 1273 roku, drugi - średniowieczny herb Armenii z orłem i dwoma lwami. Dwa ekslibrisy in memoriam zaprojektował Agopsowicz dla Arama Asłana (1980). Jeden przedstawiał ruiny bazyliki w Zwartnoc pod Erywaniem na tle Araratu, drugi klasztor nad jeziorem Sewan, Ararat i ornament staroormiański ${ }^{64}$.

Ciekawe projekty zrealizował Agopsowicz dla dwóch naukowców z Krakowa, związanych ze środowiskiem ormiańskim. Dla Janusza Komockiego wykonał ekslibris z ornamentem plecionkowym, Ormianką w stroju ludowym, górą Ararat i tarczą z herbem Jelita (1971). Dla armenisty Andrzeja Pisowicza (obecnie profesora Uniwersytetu Jagiellońskiego) zaprojektował kompozycję przedstawiającą orła na wysokim obelisku w Zwartnoc, świątynię na półwyspie Sewan, kościół Karmrawor oraz Wielki i Mały Ararat (1977).

Motywy ormiańskie występowały także w kilku innych kompozycjach. Na ekslibrisie in memoriam Tadeusza Przypkowskiego (1979) znajdował się zegar słoneczny z kościoła św. Szczepana w Hagharcin w Armenii, na ekslibrisie Anny

63 Jan Hasso Agopsowicz. Ekslibrisy.

${ }^{64}$ T. T. Gudzowski, Ormiańskie ekslibrisy Jana Agopsowicza, s. 8-9; Jan Hasso Agop-

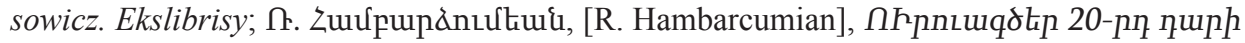
huu quinıph [Zarysy wspólnoty polsko-ormiańskiej w XX wieku], „Zuiqnłu Uưuoptuu]” [„Handes Amsorya”], 1981, 1-12, s. 139. 
Agopsowicz (1976) - ormiańscy ogrodnicy oraz napis stylizowany na ormiański. Z kolei ekslibris Emilii Agopsowicz (1980) składał się z ormiańskiego ornamentu roślinnego i napisu w języku ormiańskim. Ciekawą kompozycję posiada ekslibris Feliksa Ścibałły (1962), krakowskiego bronioznawcy i kolekcjonera, żonatego z polską Ormianką, Marią Torosiewicz. Figurował na nim ornament florystyczny i litery stylizowane na ormiańskie.

Akcenty ormiańskie w twórczości Agopsowicza charakteryzował kolekcjoner i znawca ekslibrisów Tadeusz Gudzowski:

Ekslibrisy te - podobnie jak wszystkie inne prace, które wyszły spod rylca Jana Agopsowicza - są wysoko cenione przez kolekcjonerów i znawców sztuki graficznej. Odznaczają się niezwykłą elegancją, doskonałą kompozycją graficzną i wykonaniem. Wyróżnia je również piękne ormiańskie liternictwo i typowe ozdobniki jak rajskie ptaki. Wiele uroku dodaje doskonały dobór farb i papieru, na których są tłoczone ${ }^{65}$.

Kilkanaście ekslibrisów Jan Agopsowicz wykonał dla bliższej i dalszej rodziny, po kilka dla żony Emilii oraz córek Barbary i Anny, dla zięciów oraz wnuków. Dla siostrzeńca Alfreda Oruby (syna Adeli) powstały dwa ekslibrisy z motywami muzycznymi ${ }^{66}$. Dziesięć znaków książkowych zaprojektował dla swojego przyjaciela Wiktora Franza. Nawiązywały one do jego zainteresowań: bibliofilstwa i orientalistyki. Pięć ekslibrisów (w tym trzy niezrealizowane) zaprojektował dla dr. Antoniego Knota, sześć dla Feliksa Ścibałły, w tym wspomniany wyżej z motywami ormiańskimi, pięć dla znanego kolekcjonera i orientalisty, a zarazem wieloletniego przyjaciela, Antoniego Brosza, oraz jeden dla jego żony Jadwigi.

$Z$ racji swoich kontaktów zawodowych i znajomości środowiska lekarzy i farmaceutów Agopsowicz wykonywał też ekslibrisy o tematyce medycznej. Jednym z pierwszych z 1943 roku był znak dla farmaceuty Włodzimierza Staroduba. Po wojnie zaprojektował ekslibrisy dla farmaceutów i lekarzy, m.in. dla Albina Burzy (1954), Mieczysławy Jodłowskiej (1976), Jana i Elżbiety Dubielów (1978), Rajmunda Lewandowskiego (1978). Pojawiał się w nich motyw węża Eskulapa ${ }^{67}$.

Kilkanaście ekslibrisów Agopsowicz zaprojektował dla instytucji kulturalnych w Nowym Sączu. Dla Wojewódzkiej Biblioteki Publicznej powstały ekslibrisy z wizerunkiem fundatorów książnicy, Józefem Szujskim i Józefem Wieniawą Zubrzyckim, oraz herbem miasta. Kolejne przeznaczone były dla Polskiego Towarzystwa Historycznego oraz dla Stowarzyszenia Bibliotekarzy Polskich. Kilka

${ }_{65}$ T. T. Gudzows ki, Ormiańskie ekslibrisy Jana Agopsowicza, s. 9.

${ }^{66}$ Jan Hasso Agopsowicz. Ekslibrisy.

${ }^{67}$ J. T. Czosnyka, Ekslibrisy Jana Hasso Agopsowicza, „Służba Zdrowia”, 1980, 32, S. 8. 
ekslibrisów upamiętniało ważne wydarzenia, takie jak Sądeckie Dni Literatury ${ }^{68}$. Dwa ekslibrisy zaprojektował dla Miejskiej Biblioteki w Gorlicach, w tym jeden z motywem lampy naftowej ${ }^{69}$. W ten sposób nawiązał do ważnego wydarzenia zapalenia po raz pierwszy w Gorlicach lampy zaprojektowanej przez Ignacego Łukasiewicza, wynalazcy uważanego za potomka polskich Ormian.

Jan Agopsowicz cieszył się szacunkiem w środowisku kolekcjonerów grafiki. Na jego twórczość zwróciła uwagę Julia Mękicka:

Jan Hasso Agopsowicz [...] jest grafikiem amatorem, wykonawcą ponad 100 ekslibrisów, przeważnie w klasycznym stylu bez nowatorskich zniekształceń, nawiązujący swym kunsztem do sztuki iluminatorskiej dawnych mistrzów ormiańskich. Te małe subtelne obrazki cieszą się sympatią i uznaniem wśród kolekcjonerów, chociaż nie są wykonane w tzw. grafice szlachetnej, ale jako rysuneczki do skliszowania. Będąc romantykiem swej sztuki, ofiarowuje projekty swym znajomym, a interesuje go świat roślin, kwiaty, zabytki architektoniczne, rzeźby itp. ${ }^{70}$

Wyrazem uznania środowiska artystycznego związanego z ekslibrisem był hołd złożony przez grono przyjaciół już pośmiertnie - teka z dedykowanymi mu ekslibrisami ${ }^{71}$.

Prace Agopsowicza eksponowane były na wielu wystawach krajowych i zagranicznych. Kilka autorskich ekspozycji odbyło się za życia artysty, m.in. w Lipnie w 1979 roku, zorganizowana przez Rajmunda Lewandowskiego, oraz w 1981 roku we Wrocławiu, w Dzielnicowej Bibliotece Publicznej. Ponadto ekslibrisy Agopsowicza po jego śmierci prezentowano na kilkudziesięciu wystawach krajowych i zagranicznych. Zagadnienia eksponowanej grafiki były bardzo różnorodne, podobnie jak instytucje, które organizowały ekspozycje: ośrodki kultury, samorządy, biblioteki, prywatni kolekcjonerzy. Tytułem przykładu można wymienić tematykę kilku wystaw: sport w ekslibrisie ${ }^{72}$, ekslibrisy dla kobiet ${ }^{73}$,

68 Pamięci bibliofila, „Gazeta Krakowska”, 1997, 130, s. 7; Jan Hasso Agopsowicz nie żyje, „Dunajec”, 1982, 21, s. 6; Jan Hasso Agopsowicz 1915-1982. Ex-libris, 1975-1985. Xlat W[ojewódzkiej] B[iblioteki] P[ublicznej] w Nowym Saczu, oprac. W. W cześny, Nowy Sącz 1985 (teka z ekslibrisami Jana Agopsowicza).

69 S. Szafran et al., Ignacy Łukasiewicz i jego dzieło $w$ ekslibrisie, Kraków 2004, s. $22,31$.

70 J. Mękicka, Exlibris śląski w milenijnym roku 1966, Katowice 1966, s. 14.

${ }^{71}$ Ekslibrisy wykonali: Ryszard Bandosz, Zbigniew Dolatowski, Józef Józak, Zdzisław Karpiński, Rajmund Lewandowski, Klemens Raczak, Zbigniew Strzałkowski, Adam Szczepańczyk, Tadeusz Szumarski, Bronisław Józef Tomecki, Józef Wanag. In memoriam Jana Hasso Agopsowicza.

${ }^{72}$ M. Grybel-Meksuła, A. Gauda, Sport w ekslibrisie, Lublin 1988.

7370 ekslibrisów dla kobiet. Katalog wystawy ekslibrisów z kolekcji Książnicy Pedagogicznej im. A. Parczewskiego w Kaliszu, oprac. B. Celer, Kalisz 2019. 
miasto Lublin ${ }^{74}$, ekslibrisy szachowe ${ }^{75}$, ekslibrisy sienkiewiczowskie ${ }^{76}$, motywy wojskowe $^{77}$, motywy marynistyczne ${ }^{78}$, ekslibrisy harcerskie ${ }^{79}$, z motywami ludowymi $^{80}, \mathrm{z}$ motywem orła ${ }^{81}$, upamiętniające wydarzenia historyczne ${ }^{82}$ oraz bez wiodącej tematyki pochodzące ze zbiorów znanych polskich kolekcjonerów ${ }^{83}$. Kilkadziesiąt ekslibrisów Jana Agopsowicza znalazło się na wystawie w galerii „Rytm” w Zakładowym Domu Kultury Huty im. Lenina w Krakowie w 1976 roku. Wystawę zorganizował kustosz Muzeum Etnograficznego w Krakowie Janusz Kamocki wraz ze Stanisławem Donigiewiczem. Agopsowicz był jedynym autorem z Polski, pozostałych 14 artystów pochodziło z Armenii ${ }^{84}$.

Intensywne kontakty Agopsowicza z ormiańskim środowiskiem artystycznym spowodowały, że jego twórczością zainteresowano się także w Armenii. Pięć prac Agopsowicza było eksponowanych na wystawie: „Znaki książkowe ormiańskich artystów", zorganizowanej w październiku 1975 roku w Bibliotece im. Aleksandra Miasnikiana (obecnie Biblioteka Narodowa Armenii) w Erywaniu $^{85}$. W 1977 roku na analogicznej wystawie wystawiono jego 17 ekslibrisów ${ }^{86}$, a w kolejnym roku $12^{87}$.

${ }^{74}$ Lublin - ludzie i zabytki w ekslibrisie, oprac. A. Gauda, Lublin 1997, s. 27.

75200 exlibrisów szachowych ze zbiorów Jerzego Giżyckiego i Włodzimierza Pawlaka, Warszawa 1980, s. 9. Ekslibrisy szachowe ze zbioru Jerzego Giżyckiego, Częstochowa 1984.

${ }^{76}$ Międzynarodowa wystawa ekslibrisów sienkiewiczowskich, oprac. J. T. Czosnyka, Pruszków 1996, s. 15.

${ }_{77}$ Polski ekslibris wojskowy, Warszawa, maj 1983, druk ulotny.

78 Wystawa ekslibrisu morskiego, Gdynia 1980, druk ulotny.

79 Wystawa ekslibrisów harcerskich z okazji siedemdziesięciolecia harcerstwa polskiego, Tarnów 1980.

${ }^{80}$ Motywy ludowe w ekslibrisie. Wystawa ze zbiorów Haliny i Zdzisława Dąbków, Żagań 1986.

${ }^{81}$ Orzeł $w$ ekslibrisie. Katalog wystawy ekslibrisów z kolekcji Józefa Tadeusza Czosnyki z Wojcieszowa, Słupsk 1983; Motyw orła w exlibrisie z kolekcji Józefa Tadeusza Czosnyki z Wojcieszowa, Elbląg 1984.

${ }^{82}$ Ekslibrisy 40-lecia Polski Ludowej, oprac. J. T. Czosnyka, Busko-Zdrój 1984, druk ulotny.

${ }^{83}$ Chess Collectors International 2nd Congress ex collectione Jerzy Giżycki, London 1986.

${ }^{84}$ Katalog pierwszej wystawy exlibrisu ormiańskiego artystów z Armenii i Polski, Kraków, 1976, druk ulotny.

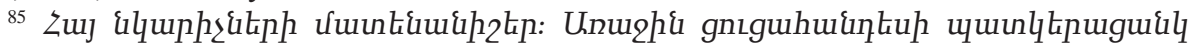
1975 p. hnluntúfkp [Ekslibrisy ormiańskich artystów: katalog pierwszej wystawy 1975 roku październik], oprac. U. \uqupju氏 [S. Ghazaryan], Epluud [Erywań] 1975, s. 27.

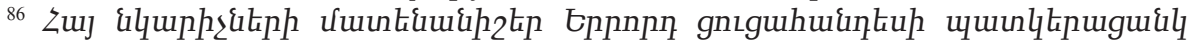
1977 p. hnluntưpten [Ekslibrisy ormiańskich artystów: katalog trzeciej wystawy 1977 roku październik], oprac. U. २ uquupjư [S. Ghazaryan], Eplıu\{ [Erywań] 1977, s. 9.

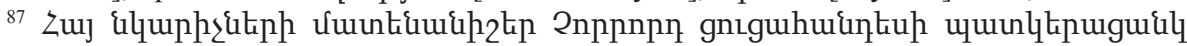
1978 p. hnluntuuplep, [Ekslibrisy ormiańskich artystów: katalog czwartej wystawy 1978 roku październik], oprac. U. २ uqupjuq [S. Ghazaryan], Epluuiq [Erywań] 1978, s. 10-11. 
Ekslibrisy Agopsowicza zasiliły zbiory krajowe i zagraniczne, zarówno prywatne, jak i instytucji państwowych, takich jak: Biblioteka Kórnicka Polskiej Akademii Nauk, Biblioteka Jagiellońska w Krakowie, Biblioteka Naukowa PAN i PAU w Krakowie, Biblioteka Zakładu Narodowego im. Ossolińskich we Wrocławiu i inne.

Kilku znanych artystów - poza wspomnianym już Rudolfem Mękickim - wykonało dla Agopsowicza ekslibrisy. Byli to: Zygmunt Acedański, Zbigniew Dolatowski, Jerzy Drużycki, Rajmund Lewandowski, Zbigniew Lubicz-Miszewski, Aszot Mamadżanian, Klemens Raczak, Zbigniew Strzałkowski, Tadeusz Szumarski, Józef Wanag ${ }^{88}$. Jako ciekawostkę warto nadmienić, że w 1962 roku z inicjatywy Agopsowicza i według jego wskazówek Zbigniew Dolatowski wykonał w drzeworycie ekslibris dla kard. Agadżaniana i dla ks. Grzegorza Petrowicza ${ }^{89}$.

Jan Hasso Agopsowicz posiadał również własną kolekcję ekslibrisów artystów polskich i zagranicznych, zwłaszcza ormiańskich ${ }^{90}$. Niektóre z nich były eksponowane na wystawie zorganizowanej w Wojewódzkiej Bibliotece Publicznej im. Józefa Szujskiego w Nowym Sączu w maju 1977 roku ${ }^{91}$. Swoje zbiory powiększał drogą wymiany z innymi kolekcjonerami ${ }^{92}$.

88 Rajmund Lewandowski. Grafika - exlibris. Katalog wystawy, oprac. W. Wcześny, Nowy Sącz 1979; Zbigniew Dolatowski. Ekslibrisy i grafika ksiązkowa, oprac. J. Saffarini, Warszawa 2001; Grafika Rajmunda Lewandowskiego, oprac. J. Kolek, W. Pawlak, Warszawa 1981, s. 12; T. Suma, Jan Hasso Agopsowicz, http://ekslibrispolski.pl/?page_id=2136 (dostęp: 27 stycznia 2021).

${ }^{89}$ AFKiDOP: SSD, sygn. 125, s. 1, list J. Agopsowicza do S. Donigiewicza, Nowy Sącz, 28 marca 1977; Zbigniew Dolatowski. Ekslibrisy i grafika książkowa.

${ }^{90}$ Byli to m.in.: Irena Nowakowska-Acedańska, Zygmunt Acedański, Tadeusz Andrusiewicz, Jerzy Bandura, Stefania Gebus-Baraniecka, Wojciech Barylski, Czesław Borowczyk, W. J. Breitner, Bogusław Brandt, Marek Brudnicki, Andrzej Buchaniec, Adam Bunsch, Stanisław Ostoja-Chrostowski, Tadeusz Cieślewski, Stanisław Dawski, Zbigniew Dolatowski, Jerzy Drużycki, Antoni Gołębniak, Stanisław Grabczyk, Edward Grabowski, Stanisław Jakubowski, Wojciech Jakubowski, Jerzy Jarnuszkiewicz, W. Kaczorowski, Alina Kalczyńska-Scheiwiller, Lesław Kasprzycki, Czesław Kelma, Wanda Korzeniowska, Ryszard Krzywka, Jan Kurkiewicz, Wiktor Langner, Wojciech Łuczak, Antoni Madeyski, Jan Maniecki, Bogusław Marschall, Adam Młodzianowski, Stanisław Mrowiński, Stefan Mrożewski, Jerzy Napieracz, Jan Olejniczak, Halina Pawlikowska, Adam Pohorecki-Czaplic, Edwarda Przeorska, Tadeusz Przypkowski, Klemens Raczak, Stanisław Raczyński, Ł. Rogoziński, Stanisław Rolicz, Teodor Różankowski, Jerzy Różański, Konstanty Sopoćko, Jan Stańda, Beata Słuszkiewicz, Jan Marcin Szancer, Józef Szuszkiewicz, Janusz Tłomakowski, Stanisław Töpfer, Tadeusz Tuszewski, Ludwik Tyrowicz, Franciszek Walczowski, Zygmunt Waśniewski, Tyrsus Wenhrynowicz, Kazimierz Wiszniewski, Marian Wójciak, Krystyna Wróblewska, Stanisław Zgaiński, Tadeusz Żurowski.

${ }^{1}$ Katalog wystawy exlibrisu ze zbiorów Jana Hasso Agopsowicza, Nowy Sącz 1977, druk ulotny.

${ }^{92}$ AFKiDOP: SSD, sygn. 52, s. 8, list J. Agopsowicza do S. Donigiewicza, Nowy Sącz, 2 czerwca 1980. 
Szerokie zainteresowania Jana Agopsowicza odzwierciedlał obszerny księgozbiór, który zebrał. Gromadził książki w języku polskim, ormiańskim i językach zachodnich, przede wszystkim wydawnictwa dotyczące Ormian i Armenii, publikacje z historii sztuki (zwłaszcza albumy), literaturę piękną, opracowania historyczne, wydawnictwa ekslibrisologiczne. Kolekcjonowanie książek rozpoczął jeszcze we Lwowie i skupił się przede wszystkim na armenicach, których do końca drugiej wojny światowej miał zebrać około 4000 druków: książek, broszur i czasopism w różnych językach, często publikacji rzadkich. Nie wszystko zdołał jednak przewieźć do Polski, gdyż część tej kolekcji zaginęła w zawierusze wojennej ${ }^{93}$. Po wojnie kontynuował pasję bibliofila-armenisty, skrzętnie gromadząc literaturę dotyczącą historii Armenii, zwłaszcza dziejów Ormian w Polsce i krajach ościennych. Kupował nowości wydawnicze, śledził rynek antykwaryczny, korespondował w sprawie wydawnictw armenistycznych ${ }^{94}$. Sprowadzał książki z Armenii, w tym wydawnictwa encyklopedyczne ${ }^{95}$. Szereg publikacji o tematyce armenistycznej i ekslibrisologicznej przysyłali mu znajomi z Armenii, m.in. Rafael Hambarcumian z Erywania ${ }^{96}$.

Jan Agopsowicz interesował się także fotografią, brał udział w licznych wystawach i konkursach. Fotografował przeważnie postacie, obiekty sakralne i naturę $^{97}$. Pasjonowała go muzyka poważna i opera, posiadał obszerną płytotekę, którą uzupełniał podczas wizyt we Włoszech ${ }^{98}$.

\section{Badania genealogiczne}

Jan Hasso Agopsowicz przez ponad trzydzieści lat z zaangażowaniem i pasją zajmował się badaniami nad historią i genealogią swojej rodziny. W tym celu przeprowadził szereg kwerend archiwalnych i bibliotecznych, korzystał z fachowej literatury krajowej i zagranicznej ${ }^{99}$. Sporo czasu przeznaczył na analizę tej części akt miejskich Stanisławowa z XVII i XVIII wieku, które przechowywane

93 Archiwum Archidiecezjalne Warszawskie (dalej: AAW): sygn. S. 63.35, k. 7, list J. Agopsowicza do ks. Zdzisława Obertyńskiego, Nowy Sącz, 29 czerwca 1959;

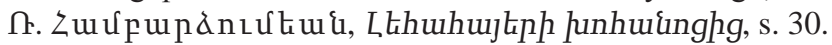

${ }^{94}$ AAW: sygn. S. 63.26, k. 140, list J. Agopsowicza do ks. Z. Obertyńskiego, Nowy Sącz, 6 maja 1960.

${ }^{95}$ Archiwum Nauki PAN i PAU w Krakowie (dalej: AN PAN i PAU): sygn. KIII-144, list J. Agopsowicza do Czesława Lechickiego, Nowy Sącz, 11 marca 1980, b. pag.

96 AFKiDOP: SSD, sygn. 52, s. 2, list J. Agopsowicza do S. Donigiewicza, Nowy Sącz, 6 maja 1980; s. 8, list tegoż do tegoż, Nowy Sącz, 2 czerwca 1980.

97 Relacja Anny Agopsowicz Paczki, Kraków, 15 lutego 2021 roku.

98 B. Agopsowicz-Krasowska, Jan Józef Hasso Agopsowicz, s. 84; Relacja Barbary Agopsowicz Krasowskiej, Kraków, 4 marca 2021 roku.

99 AN PAN i PAU: sygn. KIII-144, list J. Agopsowicza do Cz. Lechickiego, Nowy Sącz, 6 września 1978. 
są w Bibliotece Czartoryskich w Krakowie ${ }^{100}$. Ponadto korzystał z materiałów archiwalnych parafii ormiańskiej w Gdańsku oraz archiwów i bibliotek państwowych $^{101}$. Podejmował próby pozyskania dokumentów z Archiwum Historycznego we Lwowie i Archiwum Obwodowego w Czerniowcach, chcąc dotrzeć do dokumentacji związanej ze szlachectwem swych przodków ${ }^{102}$. Uważał, że jego antenaci przybyli do Mołdawii po upadku ormiańskiego Królestwa Cylicji w 1375 roku, co było ustaleniem mylnym. Miał tu na myśli Kirkora Hasso, o którym twierdził, że zmarł w roku $1428^{103}$. Bez wątpienia w XVIII wieku jego rodzina mieszkała w okolicach Stanisławowa ${ }^{104}$. Nazwisko Agopsowicz pochodziło - jego zdaniem - z tego właśnie czasu, a poprzednio używana była nazwa rodowa „Hasso" ${ }^{105}$.

Prace nad genealogią zintensyfikował po przejściu na emeryturę. Miał wówczas więcej czasu na systematyzowanie i uzupełnianie informacji genealogicznych ${ }^{106}$. Wieloletni wysiłek, kwerendy i korespondencja z członkami rodziny przyniosły wymierny efekt w postaci pracy Genealogia rodu Hasso Agopsowiczów 1428-1978 (Nowy Sącz 1978). Opracowanie poprzedził szkicem o historii Armenii, zamieścił w niej drzewa genealogiczne oraz wspomnienia o najbliższej rodzinie. Maszynopis własnoręcznie oprawił w pergamin oraz ozdobił miniaturami na wzór średniowiecznych kodeksów ormiańskich ${ }^{107}$. Autor nie miał wykształcenia historycznego ani profesjonalnego przygotowania w zakresie badań genealogicznych; sam doskonalił umiejętności warsztatowe i interpretował pozyskany materiał źródłowy.

100 Wypisał ponadto wszystkie występujące w źródle nazwiska ormiańskie i ten materiał przekazał Michałowi Bohosiewiczowi z Gliwic. AFKiDOP: SSD, sygn. 52, s. 14, list J. Agopsowicza do S. Donigiewicza, Nowy Sącz, 24 czerwca 1980; s. 16, list tegoż do tegoż, Nowy Sącz, 14 lipca 1980.

${ }^{101}$ Ibidem, s. 14, list tegoż do tegoż, Nowy Sącz, 24 czerwca 1980.

102 AN PAN i PAU: sygn. KIII-144, list J. Agopsowicza do Cz. Lechickiego, Nowy Sącz, 23 maja 1978; list tegoż do tegoż, Nowy Sącz, 6 września 1978, b. pag.

103 AN PAN i PAU: sygn. KIII-144, list J. Agopsowicza do Cz. Lechickiego, Nowy Sącz, 23 maja 1978.

${ }^{104}$ AFKiDOP: SSD, sygn. 52, s. 14, list J. Agopsowicza do S. Donigiewicza, Nowy Sącz, 24 czerwca 1980.

105 AN PAN i PAU: sygn. KIII-144, list J. Agopsowicza do Cz. Lechickiego, Nowy Sącz, 23 maja 1978.

106 AFKiDOP: SSD, sygn. 52, s. 18, list J. Agopsowicza do S. Donigiewicza, Nowy Sącz, 28 lipca 1980.

${ }^{107}$ APFRK, list J. Agopsowicza do o. J. M. Pasiecznika, Nowy Sącz, 15 kwietnia 1981;

B. Agopsowicz-Krasowska, Jan Józef Hasso Agopsowicz, s. 84. 


\section{Osobowość}

Jan Agopsowicz utrzymywał kontakt z wieloma znajomymi w kraju i zagranicą. Prowadził rozległą korespondencję, poruszając w niej przeważnie sprawy środowiska i obrządku ormiańskiego, rodzinnej genealogii oraz zagadnienia związane z kolekcjonowaniem i tworzeniem ekslibrisów. Był bardzo gościnny, często odwiedzali go znajomi i rodzina, zatrzymując się nawet na dłuższy pobyt $^{108}$. Czwartki zarezerwowane były na spotkania w gronie znajomych i grę w brydża. Częstym gościem był Stanisław Donigiewicz, człowiek o szerokich zainteresowaniach, z którym Agopsowicz dyskutował na tematy związane z Ormianami ${ }^{109}$. Bywał też u niego ks. Kazimierz Filipiak z Gdańska ${ }^{110}$. Wiele razy swój urlop u Agopsowiczów spędzał ks. Grzegorz Petrowicz z Rzymu, a kontakty rodziny z nim przetrwały także po śmierci Agopsowicza ${ }^{111}$. Przyjaźnił się z Różą i Grzegorzem Agopsowiczami z Wrocławia, Michałem Bohosiewiczem z Gliwic, prof. Antonim Jakubowiczem z Gliwic. Spośród znajomych z Armenii stały kontakt korespondencyjny utrzymywał ze Spartakiem Ghazarianem, Aszotem Mamadżanianem, Stanisławem Pawłowiczem, Rafaelem Hambarcumianem, którego bardzo cenił za publikacje na temat Ormian polskich ${ }^{112}$. Przyjaźnił się też z Wiktorem Franzem, i podziwiał jego erudycję ${ }^{113}$, oraz ze znanym krakowskim kolekcjonerem Antonim Broszem ${ }^{114}$.

$\mathrm{Na}$ podkreślenie zasługują umiejętności językowe Agopsowicza. Oprócz starożytnej greki i łaciny, których znajomość wyniósł jeszcze z gimnazjum, biegle posługiwał się językiem staroormiańskim ${ }^{115}$, nowoormiańskim $\mathrm{w}$ wersji

108 AFKiDOP, list J. Agopsowicza do ks. Kazimierza Filipiaka, Nowy Sącz, 20 września 1973.

109 Relacja Barbary Agopsowicz Krasowskiej, Kraków, 4 marca 2021 roku.

110 AFKiDOP: SSD, sygn. 52, s. 16, list J. Agopsowicza do S. Donigiewicza, Nowy Sącz, 14 lipca 1980.

111 Relacja Barbary Agopsowicz Krasowskiej, Kraków, 4 marca 2021 roku.

112 Archiwum Ośrodka Badań nad Kulturą Ormiańską w Polsce Polskiej Akademii Umiejętności: list J. Agopsowicza do Janusza Kamockiego, Nowy Sącz, 16 kwietnia 1975; list tegoż do tegoż, Nowy Sącz, 3 listopada 1977; AFKiDOP: SSD, sygn. 125, s. 2, list J. Agopsowicza do S. Donigiewicza, Nowy Sącz, 28 marca 1977; AN PAN i PAU: sygn. KIII-144, list J. Agopsowicza do Cz. Lechickiego, Nowy Sącz, 14 kwietnia 1979; list tegoż do tegoż, Nowy Sącz, 1 kwietnia 1980.

113 AN PAN i PAU: sygn. KIII-144, list J. Agopsowicza do Cz. Lechickiego, Nowy Sącz, 6 września 1978.

114 Biblioteka Jagiellońska, sygn. Przyb. 252/05, list J. Agopsowicza do Jadwigi Brosz, Nowy Sącz, 14 lutego 1979.

115 Świadczy o tym chociażby fakt, że ks. Dionizy Kajetanowicz przed wydaniem swoich prac z zakresu liturgii ormiańskiej konsultował z Agopsowiczem thumaczenia niektórych fragmentów. APFRK: list J. Agopsowicza do o. J. M. Pasiecznika, Nowy Sącz, 8 września 1975. 
zachodniej, włoskim, rosyjskim, francuskim, niemieckim ${ }^{116}$. Umiejętności lingwistyczne były przydatne do utrzymywania międzynarodowych kontaktów oraz korzystania z literatury. Na znajomość języka ormiańskiego zwrócili uwagę sami Ormianie podczas pobytu Agopsowicza w Erywaniu, doceniając poprawność i literacki styl wypowiedzi ${ }^{117}$.

Jan Agopsowicz był człowiekiem wielkiej kultury, humanistą o szerokich horyzontach i wielu umiejętnościach, które ciągle doskonalił. Miał spokojne usposobienie, był wrażliwy i chętny do pomocy innym, pracowity, zaangażowany w aktywność zawodową. Zapamiętany został jako świetny fachowiec w zakresie pracy laboratoryjnej oraz dobry, szlachetny i życzliwy człowiek o dojrzałej osobowości, a nadto miłośnik i popularyzator książki i ekslibrisu oraz kolekcjoner dobrej grafiki ${ }^{118}$.

Jan Hasso Agopsowicz przez wiele lat zmagał się z problemami zdrowotnymi, zmarł 30 maja 1982 roku w Nowym Sączu. Nabożeństwo pożegnalne odbyło się 2 czerwca w kaplicy na cmentarzu komunalnym w Nowym Sączu, a 4 czerwca pogrzeb na cmentarzu Rakowickim w Krakowie ${ }^{119}$. Nekrologi informujące o jego śmierci zamieściła lokalna prasa ${ }^{120}$. Został pochowany w grobowcu Zygmunta i Stefani z Agopsowiczów Fischerów, której był bratankiem ${ }^{121}$. Po śmierci Agopsowicza gromadzona przez dziesięciolecia kolekcja książek i ekslibrisów uległa rozproszeniu. Fragmenty biblioteki pozostały w gronie rodziny. Kilkadziesiąt ekslibrisów ze zbiorów Agopsowicza rodzina przekazała do Muzeum Narodowego w Krakowie, gdzie znajdują się do dnia dzisiejszego. Kilka książek zakupiła Biblioteka Publiczna im. Józefa Szujskiego w Nowym Sączu ${ }^{122}$.

\section{Bibliografia}

\section{Źródła archiwalne}

Archiwum Archidiecezjalne w Warszawie: sygn. S. 63.35, S. 63.26, Spuścizna ks. Zdzisława Obertyńskiego

Archiwum Fundacji Kultury i Dziedzictwa Ormian Polskich w Warszawie: Spuścizna arcybiskupa Józefa Teodorowicza, sygn. 552; Spuścizna Stanisława Donigiewicza,

116 ASNS, s. 1, kwestionariusz osobowy Jana Agopsowicza, Nowy Sącz, 1960; B. Agopsowicz-Krasowska, Jan Józef Hasso Agopsowicz, s. 84; గ. Zuưupunånıúuuq, Lthuhujtiph hunhuinghg, s. 30.

117 Relacja Barbary Agopsowicz Krasowskiej, Kraków, 4 marca 2021 roku.

118 J. Koszyk, L. Mazan, W Nowym Saczu mieszka wnuk Batorego!, s. 10; Jan Hasso Agopsowicz nie żyje, s. 6; Relacja Anny Agopsowicz Paczki, Kraków, 15 lutego 2021 roku.

119 Sądecka Biblioteka Publiczna im. Józefa Szujskiego w Nowym Sączu, Oddział Zbiorów Specjalnych, klepsydra informująca o śmierci Jana Hasso Agopsowicza, Nowy Sącz, 1980.

120 Zmart Jan Hasso Agopsowicz, „Gazeta Krakowska”, 1982, 83, s. 6.

121 Relacja Anny Agopsowicz Paczki, Kraków, 15 lutego 2021 roku.

122 Relacja Barbary Agopsowicz Krasowskiej, Kraków, 4 marca 2021 roku. 
sygn. 52, sygn. 125; Spuścizna księdza Kazimierza Filipiaka; Archiwum Jakubowiczów, sygn. 79, List Jana Agopsowicza do Antoniego Jakubowicza

Archiwum Instytutu Pamięci Narodowej Oddział w Krakowie: sygn. 39/23658, Akta paszportowe Jana Agopsowicza

Archiwum Nauki PAN i PAU w Krakowie: sygn. KIII-144, Spuścizna Czesława Lechickiego

Archiwum Ośrodka Badań nad Kulturą Ormiańską w Polsce Polskiej Akademii Umiejętności: Spuścizna Janusza Kamockiego

Archiwum Państwowe w Przemyślu: sygn. 108, Spuścizna Mariana Słowika

Archiwum Prowincji Franciszkanów Reformatów w Krakowie: Korespondencja o. Jana Modesta Pasiecznika

Archiwum Szpitala Specjalistycznego im. Jędrzeja Śniadeckiego w Nowym Sączu: teczka personalna Jana Agopsowicza

Congregazione per le Chiese Orientali. Archivio Storico (Rzym): sygn. 514/31, teczka personalna Jana Hasso Agopsowicza

Sądecka Biblioteka Publiczna im. Józefa Szujskiego w Nowym Sączu, Oddział Zbiorów Specjalnych: klepsydra pogrzebowa Jana Hasso Agopsowicza

Biblioteka Jagiellońska: sygn. Przyb. 252/05, spuścizna Antoniego Brosza

Zbiory Barbary Agopsowicz Krasowskiej w Krakowie: J. Hasso Agopsowicz, Genealogia rodu Hasso Agopsowiczów 1428-1978, Nowy Sącz 1978, mszps

Zbiory własne autora: Relacje Anny Agopsowicz Paczki, Kraków, 15 lutego 2021 roku, i Barbary Agopsowicz Krasowskiej, Kraków, 4 marca 2021 roku

\section{Źródła drukowane}

Agopsowicz-Krasowska B., Jan Józef Hasso Agopsowicz, „Gdzie szum Prutu”, 12, 2001, 2, s. 84

Chess Collectors International 2nd Congress ex collectione Jerzy Giżycki, London 1986 (katalog wystawy)

200 exlibrisów szachowych ze zbiorów Jerzego Giżyckiego i Włodzimierza Pawlaka, Warszawa 1980 (katalog wystawy)

Ekslibrisy 40-lecia Polski Ludowej, oprac. J. T. Czosnyka, Busko Zdrój 1984 (katalog wystawy)

Ekslibrisy szachowe ze zbioru Jerzego Giżyckiego, Częstochowa 1984 (katalog wystawy) Grafika Rajmunda Lewandowskiego, oprac. J. Kolek, W. Pawlak, Warszawa 1981

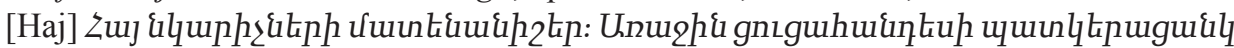
1975 p. hnluntúften [Ekslibrisy ormiańskich artystów: katalog pierwszej wystawy 1975 roku październik], oprac. U. Ququupuuq [S. Ghazaryan], Łpluud [Erywań] 1975

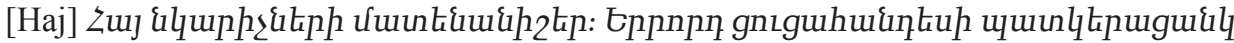
1977 p. hnluntúften [Ekslibrisy ormiańskich artystów: katalog trzeciej wystawy 1977 roku październik], oprac. U. Zuquupjui [S. Ghazaryan], Epluu氏 [Erywań] 1977

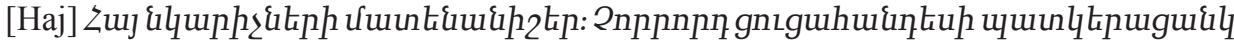
1978 p. hnluutúfpen [Ekslibrisy ormiańskich artystów: katalog czwartej wystawy 1978 roku październik] Чuqu. U. ใuquupuu\{, [oprac. S. Ghazaryan] Epluui [Erywań] 1978

Hasso Agopsowicz J., Popielniki, „Gdzie szum Prutu”, 12, 2001, 2, s. 85-91 
Jan Hasso Agopsowicz. Ekslibrisy, oprac. J. Drużycki, Nowy Sącz-Wrocław 1973

Jan Hasso Agopsowicz. Ekslibrisy. Wystawa - Wroctaw 16-26 IX 1981, oprac. M. Mazurkiewicz, Wrocław 1981

Jan Hasso Agopsowicz 1915-1982. Ex-libris. 1975-1985. X lat W[ojewódzkiej] B[iblioteki] P[ublicznej] w Nowym Saczu, oprac. W. Wcześny, Nowy Sącz 1985 [teka z ekslibrisami Jana Agopsowicza]

Jan Hasso Agopsowicz nie żyje, „Dunajec”, 1982, 21, s. 6

Katalog pierwszej wystawy exlibrisu ormiańskiego artystów z Armenii i Polski, Kraków 1976, druk ulotny

Katalog wystawy exlibrisu ze zbiorów Jana Hasso Agopsowicza, Nowy Sącz 1977, druk ulotny

Lublin - ludzie i zabytki w ekslibrisie, oprac. A. Gauda, Lublin 1997

Międzynarodowa wystawa ekslibrisów sienkiewiczowskich, oprac. J. T. Czosnyka, Pruszków 1996

Motyw orła w exlibrisie z kolekcji Józefa Tadeusza Czosnyki z Wojcieszowa, Elbląg 1984 (katalog wystawy)

Motywy ludowe w ekslibrisie. Wystawa ze zbiorów Haliny i Zdzisława Dąbków, Żagań 1986 (katalog wystawy)

Orzeł w ekslibrisie. Katalog wystawy ekslibrisów z kolekcji Józefa Tadeusza Czosnyki z Wojcieszowa, Słupsk 1983

Polski ekslibris wojskowy, Warszawa, maj 1983, druk ulotny

Pamięci bibliofila, „Gazeta Krakowska”, 1997, 130, s. 7

Rajmund Lewandowski. Grafika - exlibris. Katalog wystawy, oprac. W. Wcześny, Nowy Sącz 1979

Schematismus archidioecesis Leopoliensis ritus armeno-catholici pro Anno Domini 1932-1933, 1935-1936, 1939, Leopoli 1932-1933, 1935-1936, 1939

70 ekslibrisów dla kobiet. Katalog wystawy ekslibrisów z kolekcji Książnicy Pedagogicznej im. A. Parczewskiego w Kaliszu, oprac. B. Celer, Kalisz 2019

Sprawozdanie Dyrekcji I Gimnazjum Państwowego im. Mieczysława Romanowskiego w Stanisławowie za rok szkolny 1930/1931, Stanisławów 1931

Wystawa ekslibrisów harcerskich z okazji siedemdziesięciolecia harcerstwa polskiego, Tarnów 1980

Wystawa ekslibrisu morskiego, Gdynia, czerwiec 1980, druk ulotny

Zmart Jan Hasso Agopsowicz, „Gazeta Krakowska”, 1982, 83, s. 6

\section{Opracowania}

Agopsowicz M., Kresowe Pokucie. Rzeczpospolita Ormiańska, Łomianki 2014

Białkowski M., Prymas Stefan Wyszyński jako ordynariusz wiernych obrzadku ormiańskiego. Szkic do dziejów religijnych diaspory Ormian polskich w latach 1957-1981, „Studia Gdańskie”, 45, 2019, s. 149-171

Czosnyka J. T., Ekslibrisy Jana Hasso Agopsowicza, „Służba Zdrowia”, 1980, 32, s. 8

Dubicki T., Konspiracja polska w Rumunii 1939-1945, 1, Warszawa 2002

Grońska M., Ekslibrisy. Wiadomości zebrane dla kolekcjonerów, Warszawa 1992

Grybel-Meksuła M., Gauda A., Sport w ekslibrisie, Lublin 1988

Gudzowski T. T., Ormiańskie ekslibrisy Jana Agopsowicza, „Dunajec”, 8, 1987, 50, s. 8-9 


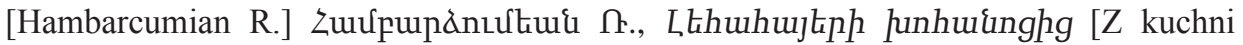
polsko-ormiańskiej], „¿ujuuunuiuh u2huuunuulnnnıhh” [„Robotnica Armenii”], 1979,2 , s. 30-31

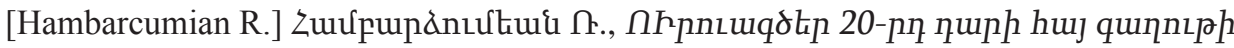
[Zarysy wspólnoty polsko-ormiańskiej w XX wieku], „ZuinnŁu Uưuoptuu]” [„Handes Amsorya"], 1-12, 1981, s. 111-142

In memoriam Jana Hasso Agopsowicza, red. J. T. Czosnyka, Nowy Sącz 1982

Koszyk J., Mazan L., W Nowym Sączu mieszka wnuk Batorego!, „Przekrój”, 1980, nr 1825, s. 10

Krzyżowski T., Archidiecezja lwowska obrządku ormiańskokatolickiego w latach 19021938, Kraków 2020

Leśniak J., Leśniak A., Agopsowicz Hasso Jan, w: Encyklopedia sadecka, Nowy Sącz 2000, s. 10

Lewandowski R., Exlibrisy Jana Hasso Agopsowicza, Lipno 1979

Mękicka J., Exlibris ślaski w milenijnym roku 1966, Katowice 1966

Migrała L., Ulica Jagiellońska w Nowym Saczu od końca XIX wieku do 1945 roku mieszkańcy i zabudowa, Nowy Sącz 2012

Mistrzowie ekslibrisu polskiego. Rudolf Mękicki, oprac. G. Kordel, [Warszawa 2019]

Nowak M. J., Mordawski Z., Opieka zdrowotna i opieka społeczna w latach 1945-1990, w: Dzieje miasta Nowego Sącza, 3, red. F. Kiryk, Z. Ruta, Kraków 1996, s. 771-806

Pełczyński G., Ormianie polscy w XX wieku. Problem odrębności etnicznej, Warszawa 1997

Suma T., Sygnatury polskich twórców ekslibrisów od XIX wieku do współczesności. Leksykon, Warszawa 2013

Szafran S. et al., Ignacy Łukasiewicz i jego dzieło w ekslibrisie, Kraków 2004

Wojciechowski M. J., Ekslibris godto bibliofila, Wrocław 1978

Zbigniew Dolatowski. Ekslibrisy i grafika ksiażkowa, oprac. J. Saffarini, Warszawa 2001

\section{Netografia}

http://ekslibrispolski.pl/?page_id=2136 (Suma T., Jan Hasso Agopsowicz)

http://ekslibrispolski.pl/?page_id=2636 [Suma T., Jan Hasso - Agopsowicz (1915-1982).

Spis kompletny]

\section{Tomasz Krzyżowski, Jan Hasso Agopsowicz (1915-1982) - Armenian, Biblio- phile, Creator of Bookplates}

Abstract: The article presents the biography of Jan Hasso Agopsowicz (1915-1982), Polish Armenian, full of merit for the Armenian environment in Poland. He was born in Kociubińce, Eastern Galicia, in the Armenian landowning family. In 19311938 he studied in Rome, at the Papal Armenian College and Gregorian University, preparing himself for the adoption of priestly orders in the Armenian rite. In October 1938 he resigned from finalisation of the theological studies and returned to Poland. After World War II, he lived in Nowy Sącz, where he was a manager of the analytical laboratory in the municipal hospital. Agopsowicz focused a lot on the situation of the Armenian diaspora in Poland and the activity of the Armenian environment. 
He wanted to guarantee the pastoral care for Catholic Armenians in Poland and to ensure the persistence of the Armenian rite so he intervened with the Holy See and Primate Stefan Wyszyński. Furthermore, he engaged in artistic activity. Creation of bookplates was his passion - he designed 240 bookplates. Interests of Agopsowicz concerning the Armenian history and culture, as well as his numerous contacts with Armenians, led to the creation of several dozen bookplates with Armenian themes. Moreover, he gathered a large book collection relating to Armenian themes in different languages. He died in Nowy Sącz and was buried at the Rakowicki Cemetery in Krakow.

Keywords: Jan Hasso Agopsowicz, Polish Armenians, Papal Armenian College, Nowy Sącz, bookplates, Armenian Catholic Church in Poland

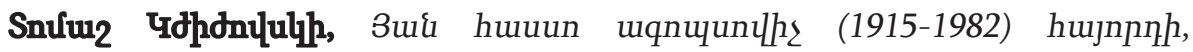

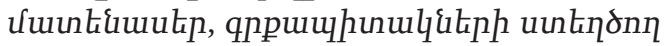

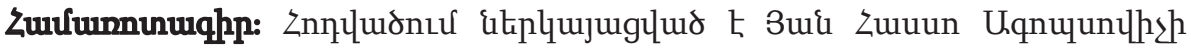

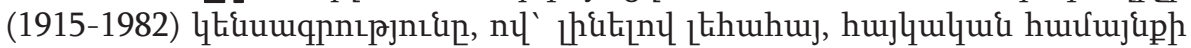

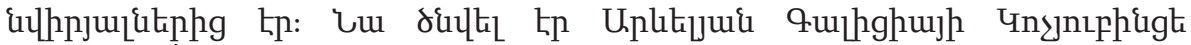

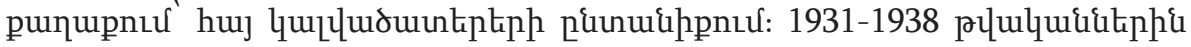

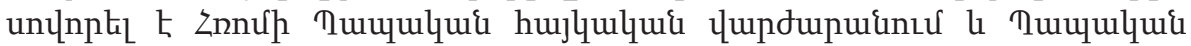

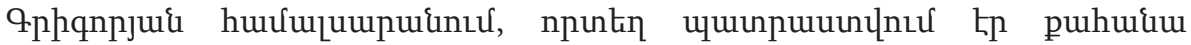

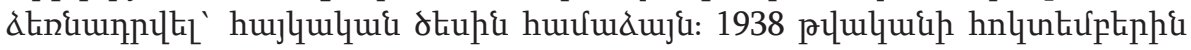

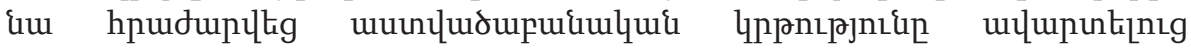

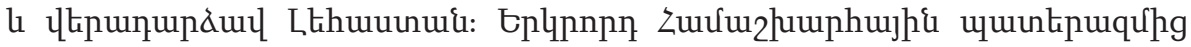

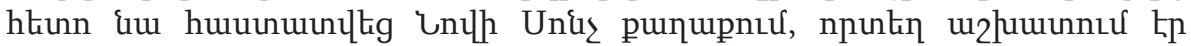

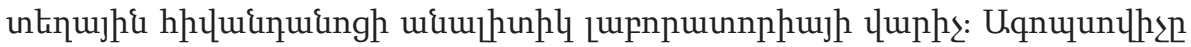

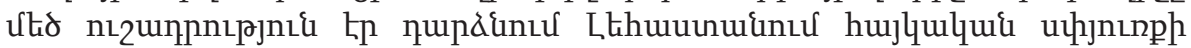

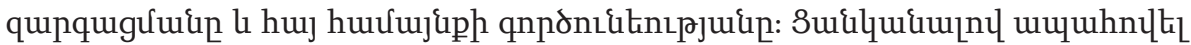

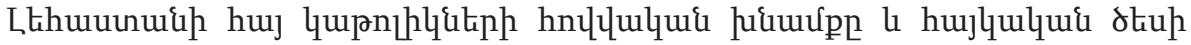

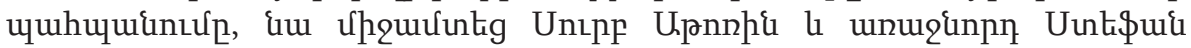

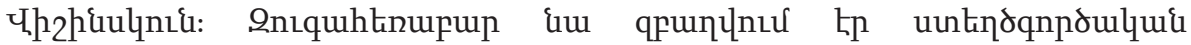

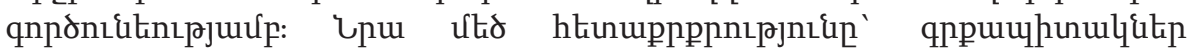
uutindt $t_{[}$k

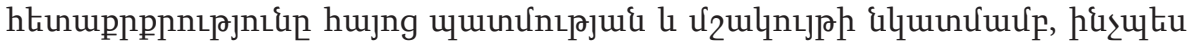

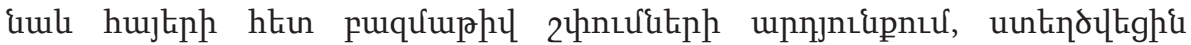

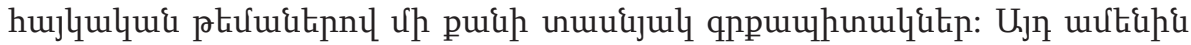

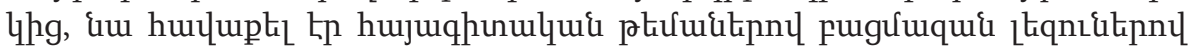

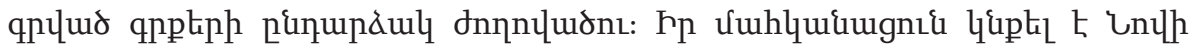

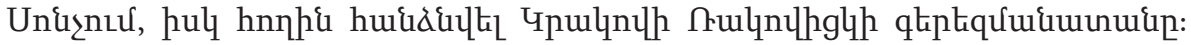

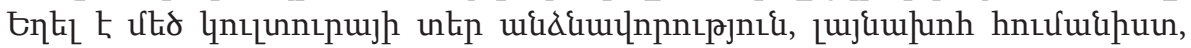
punp no uqưlulquí ưupn:

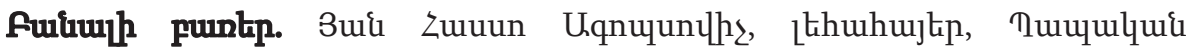

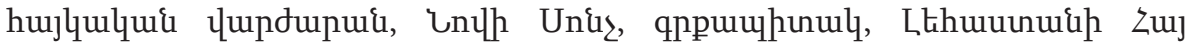
Gupnhly tilintigh: 


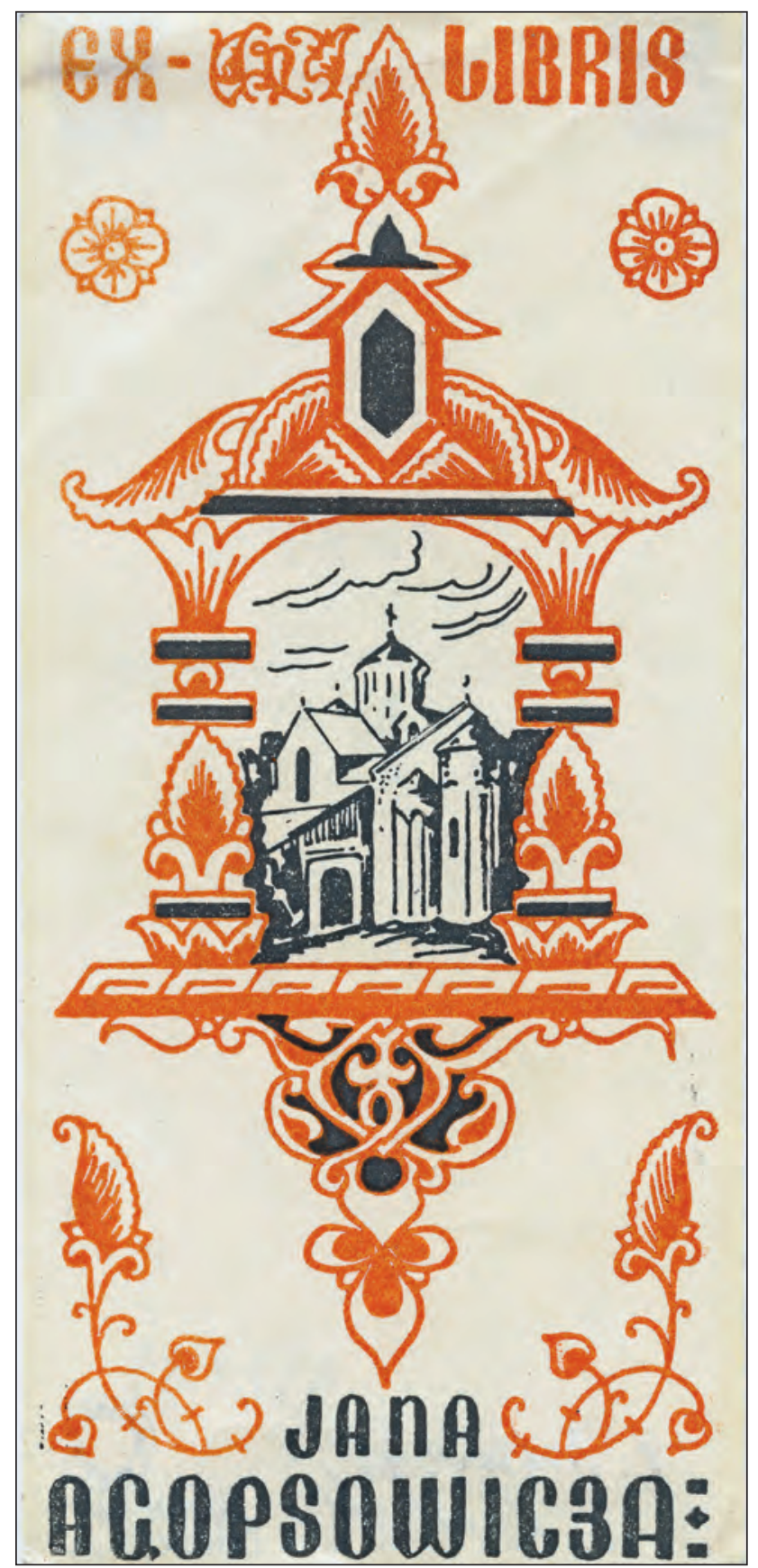

5. Rudolf Mękicki, ekslibris Jana Hasso Agopsowicza, 1942, cynkotypia barwna, Mazowiecka Biblioteka Cyfrowa 


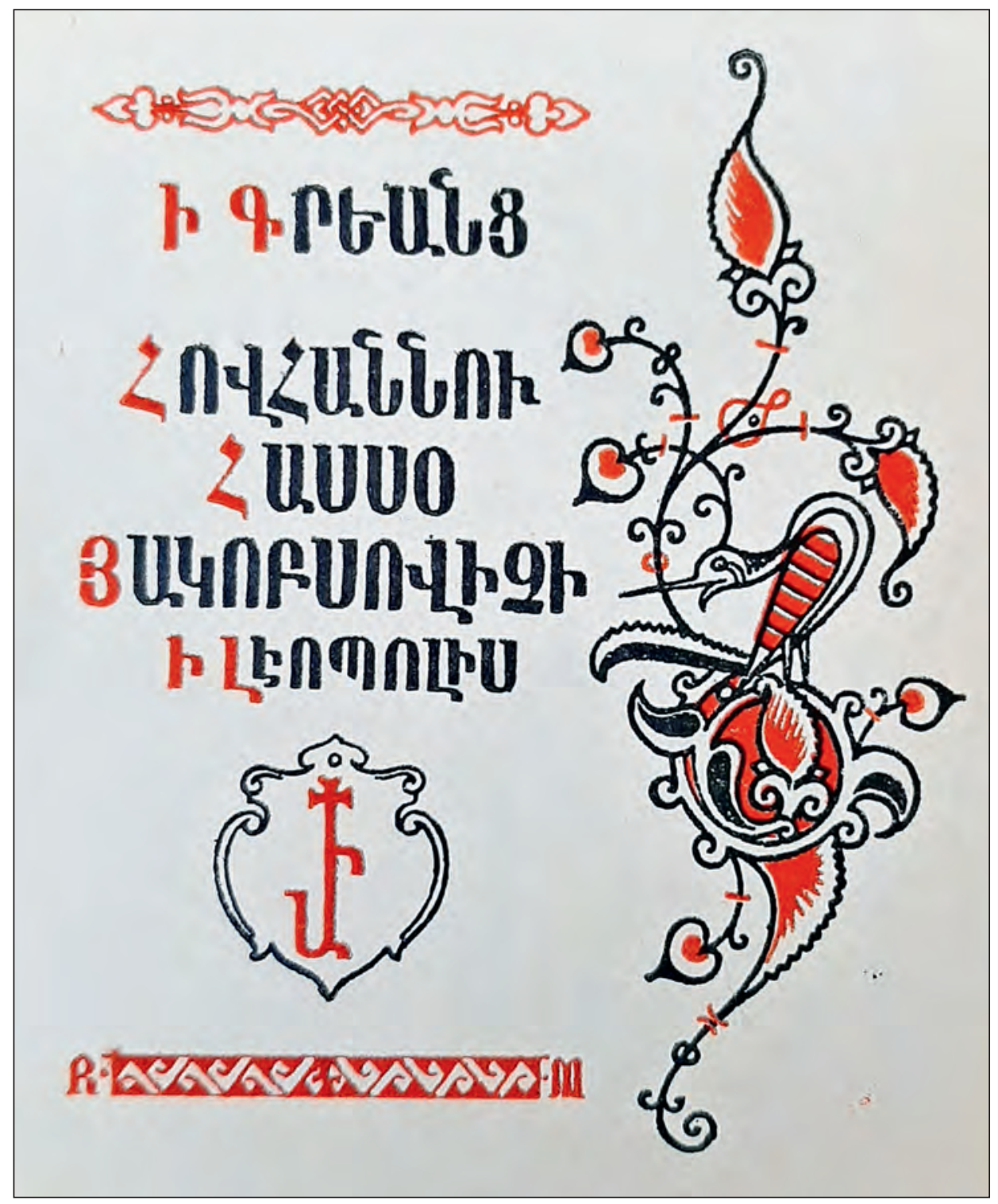

6. Rudolf Mękicki, ekslibris Jana Hasso Agopsowicza, 1942, cynkotypia barwna, zbiory autora 


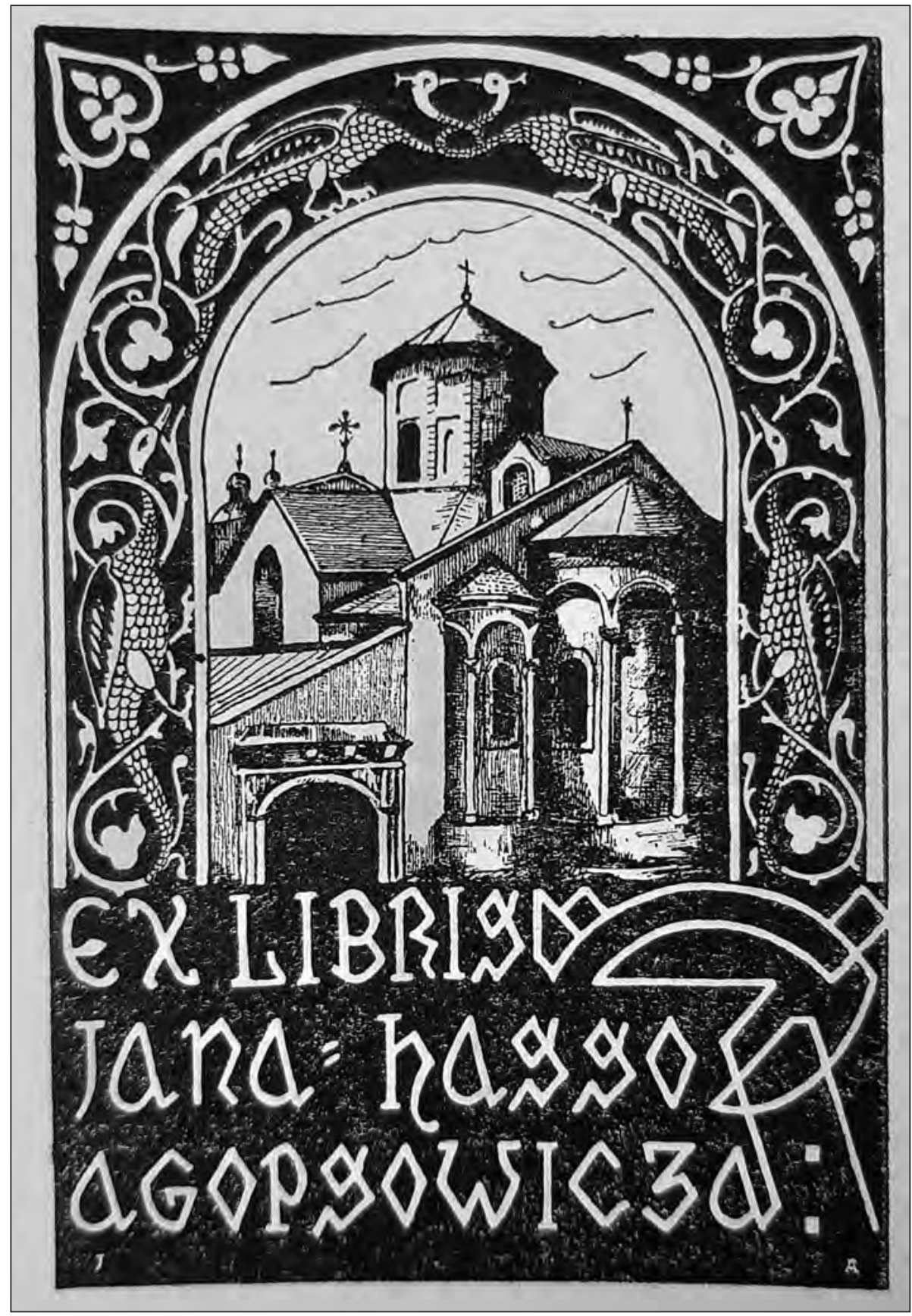

7. Autoekslibris Jana Hasso Agopsowicza, 1943, cynkotypia, zbiory autora 


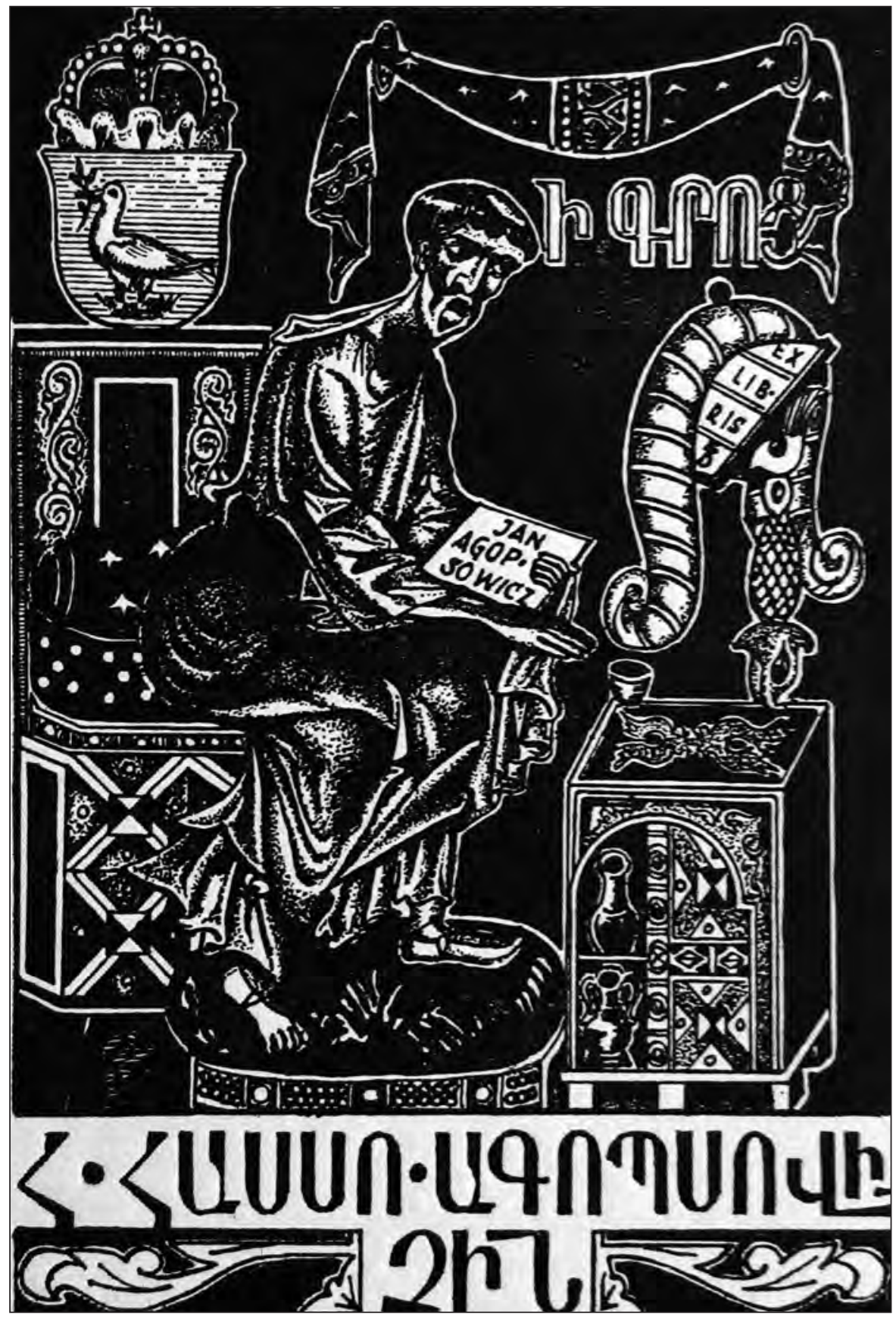

8. Autoekslibris Jana Hasso Agopsowicza, 1976, cynkotypia, Sekcja Zbiorów Graficznych i Kartograficznych Biblioteki Jagiellońskiej 


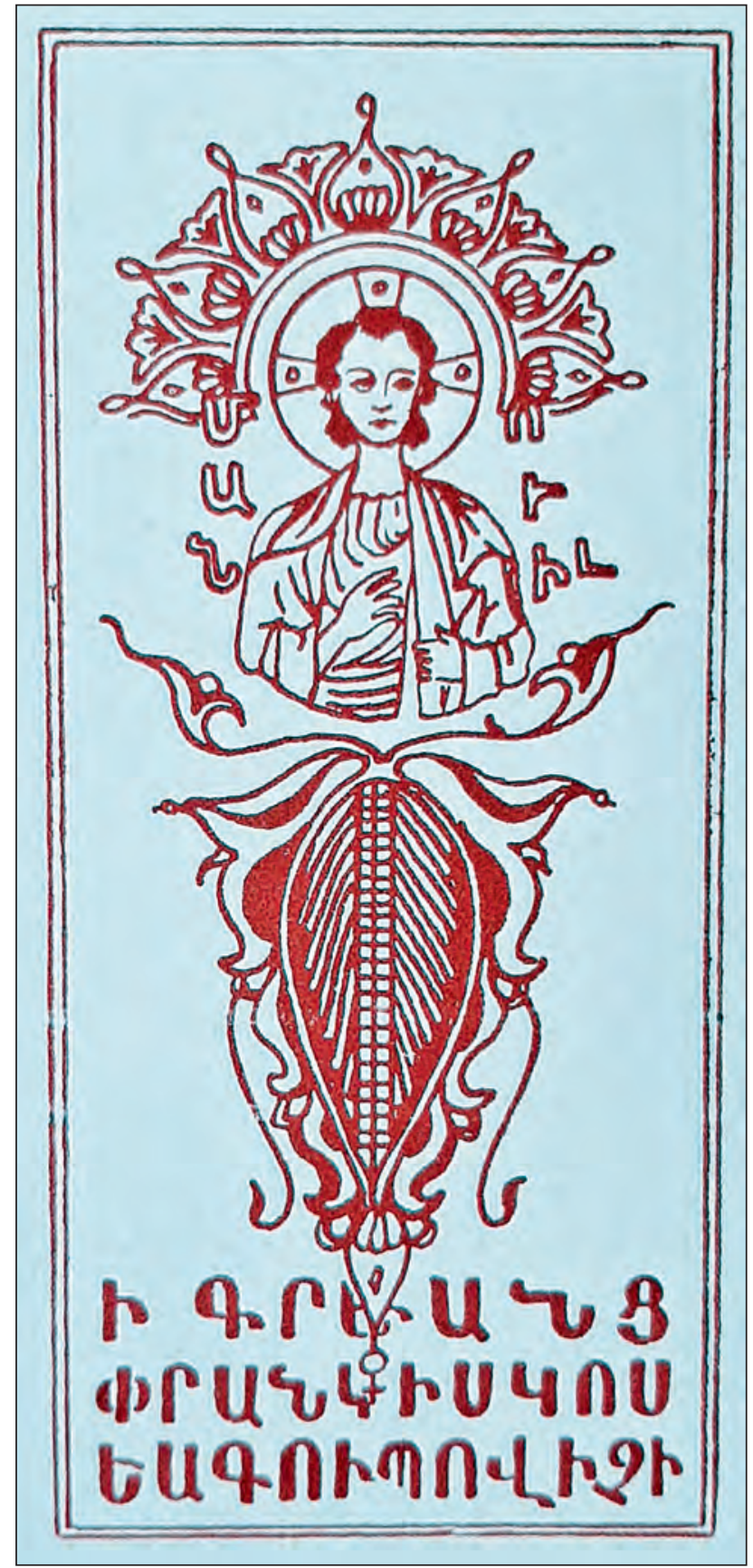

9. Jan Hasso Agopsowicz, ekslibris księdza Franciszka Jakubowicza, 1958, hektografia, zbiory autora 


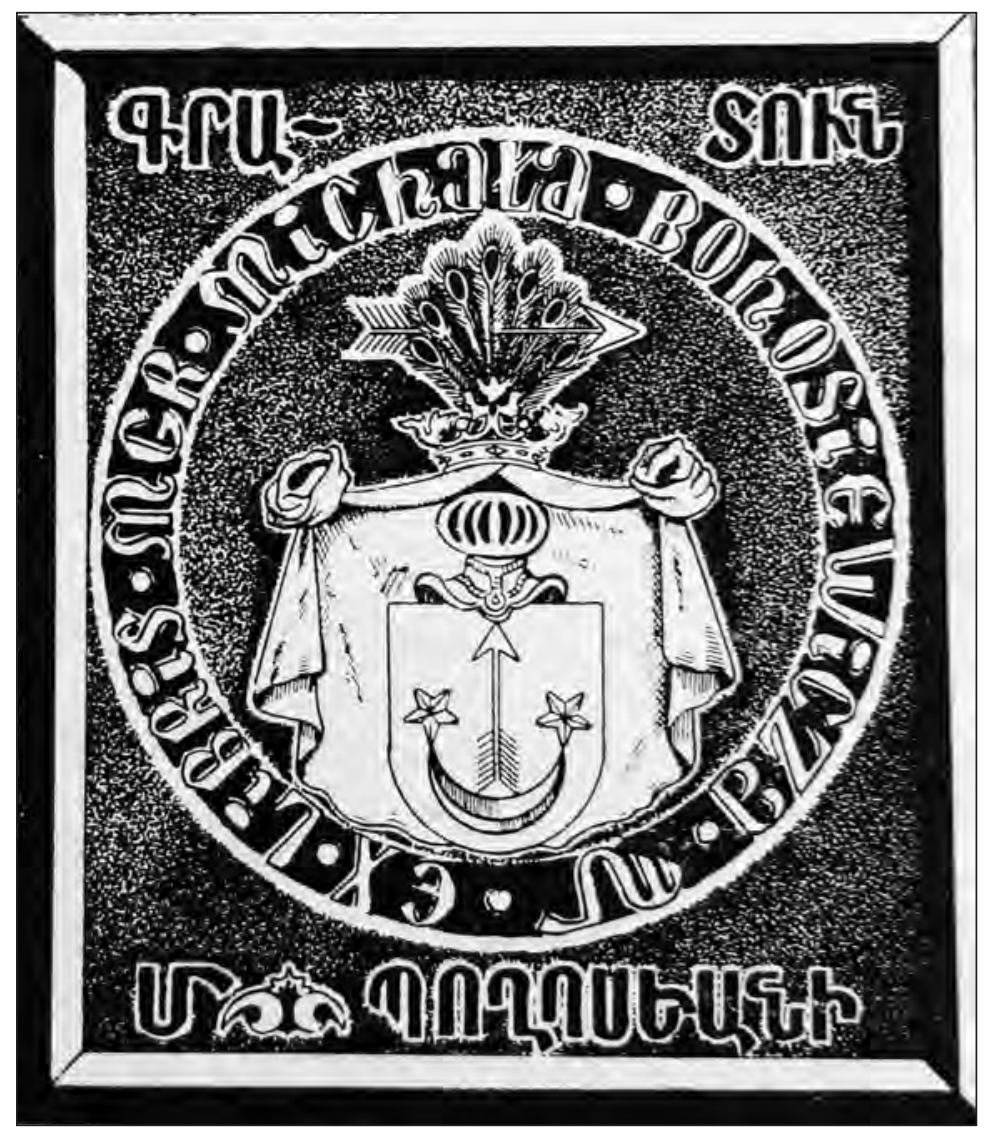

10. Jan Hasso Agopsowicz, ekslibris Michała Bohosiewicza, 1969, cynkotypia, Sekcja Zbiorów Graficznych i Kartograficznych Biblioteki Jagiellońskiej

11. Jan Hasso Agopsowicz, ekslibris Michała Bohosiewicza, 1978, cynkotypia, zbiory dr Tomasza Sumy

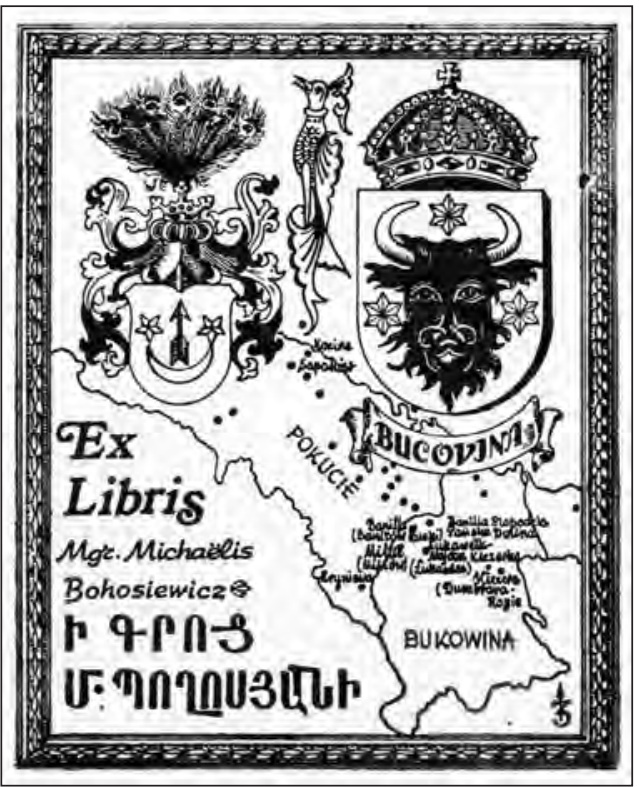




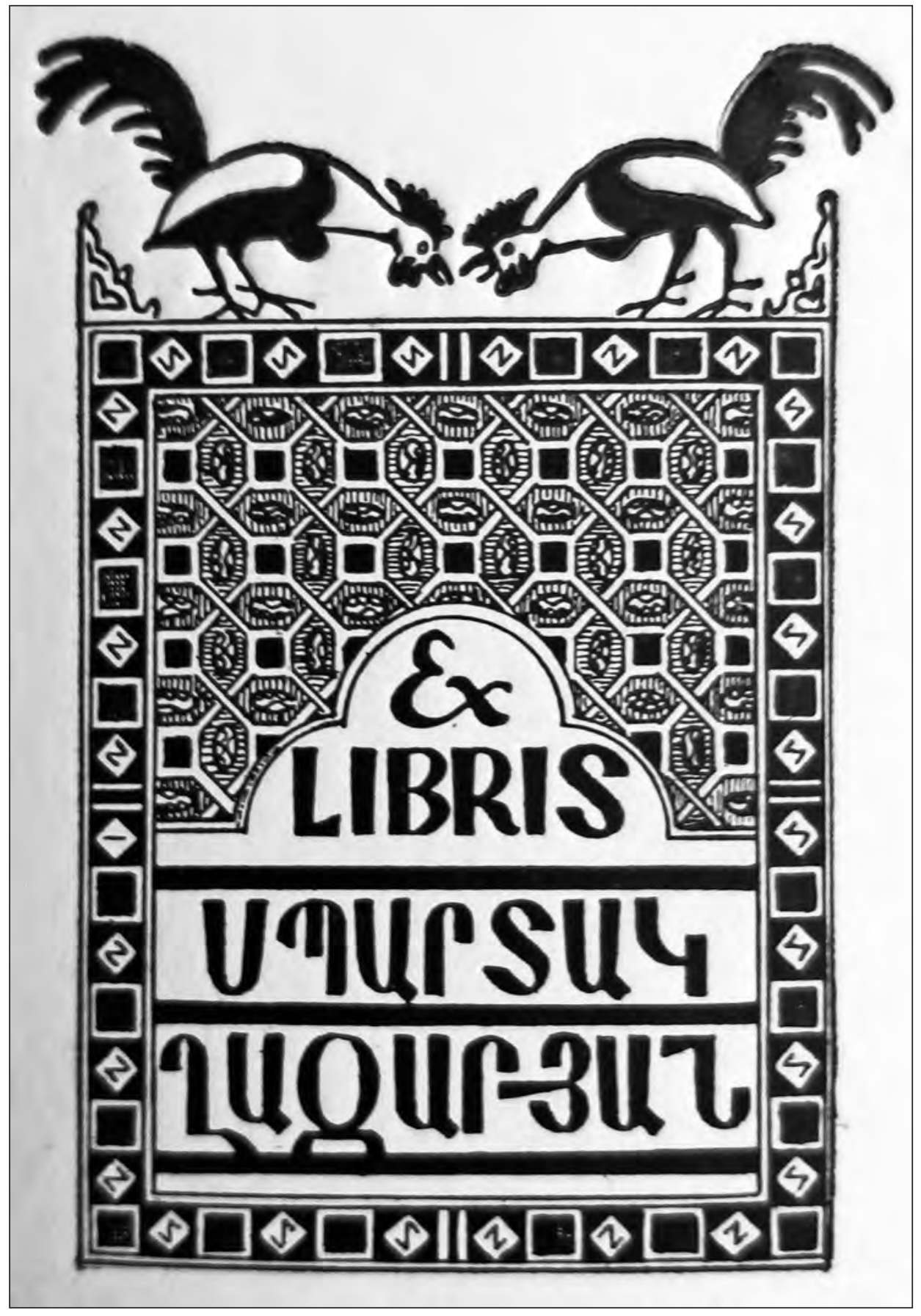

12. Jan Hasso Agopsowicz, ekslibris Spartaka Ghazariana, 1977, cynkotypia, Sekcja Zbiorów Graficznych i Kartograficznych Biblioteki Jagiellońskiej 


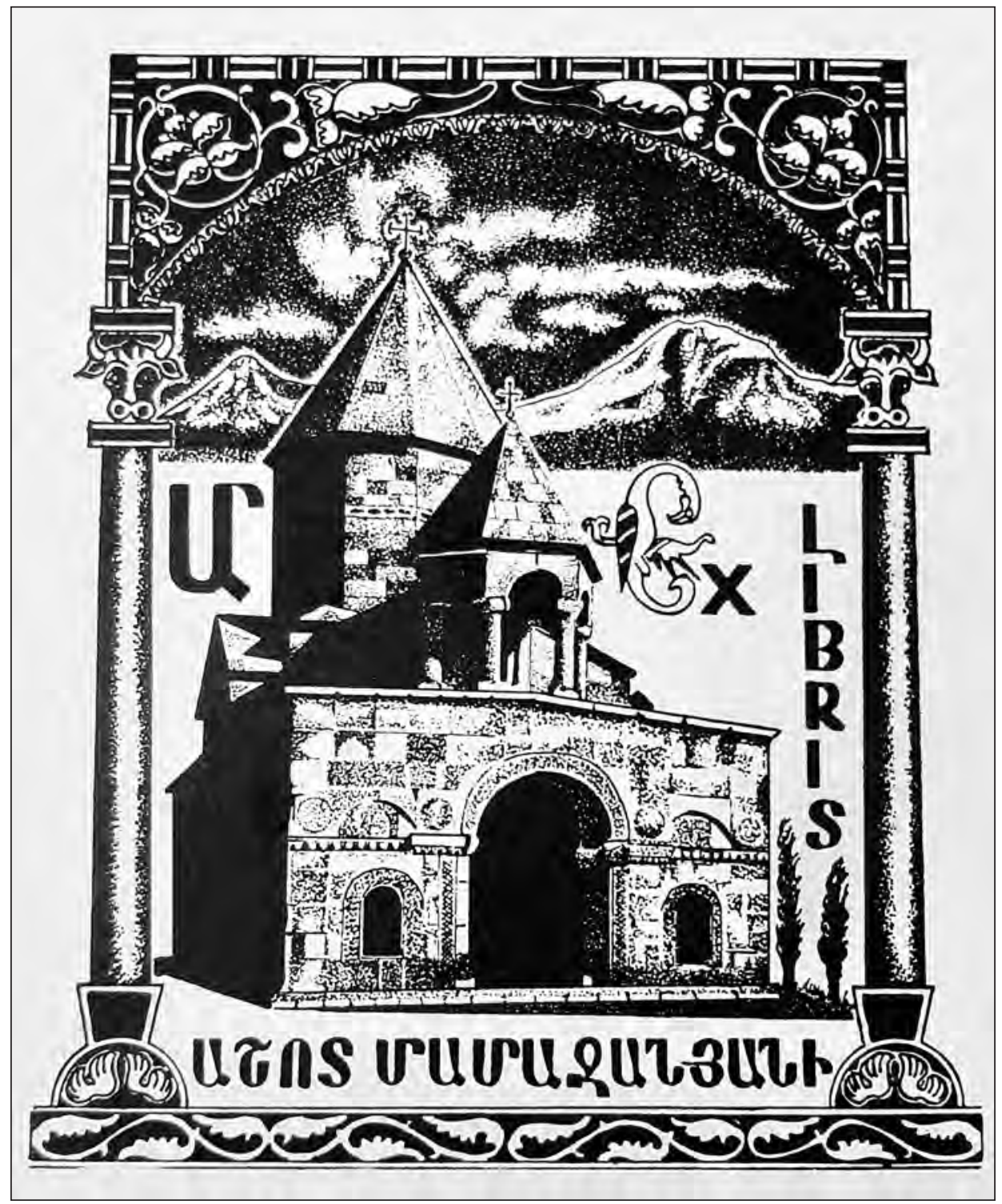

13. Jan Hasso Agopsowicz, ekslibris Aszota Mamadżaniana, 1977, cynkotypia, zbiory autora 


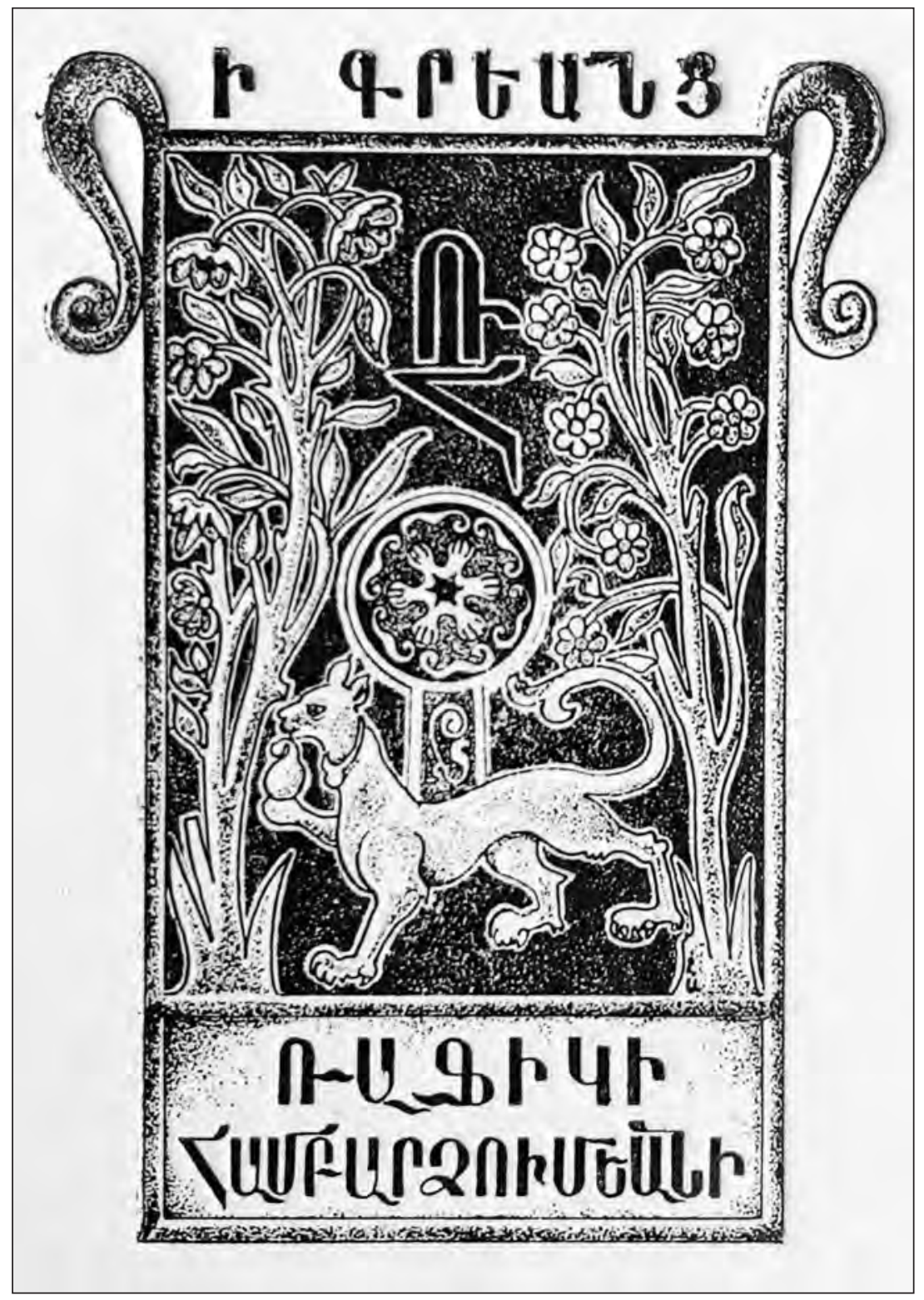

14. Jan Hasso Agopsowicz, ekslibris Rafaela Hambarcumiana, 1978, cynkotypia, Sekcja Zbiorów Graficznych i Kartograficznych Biblioteki Jagiellońskiej 


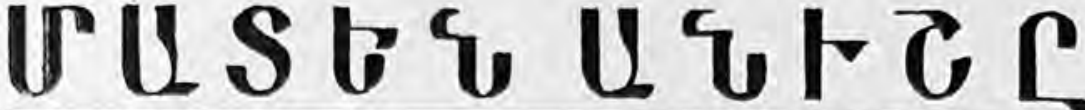

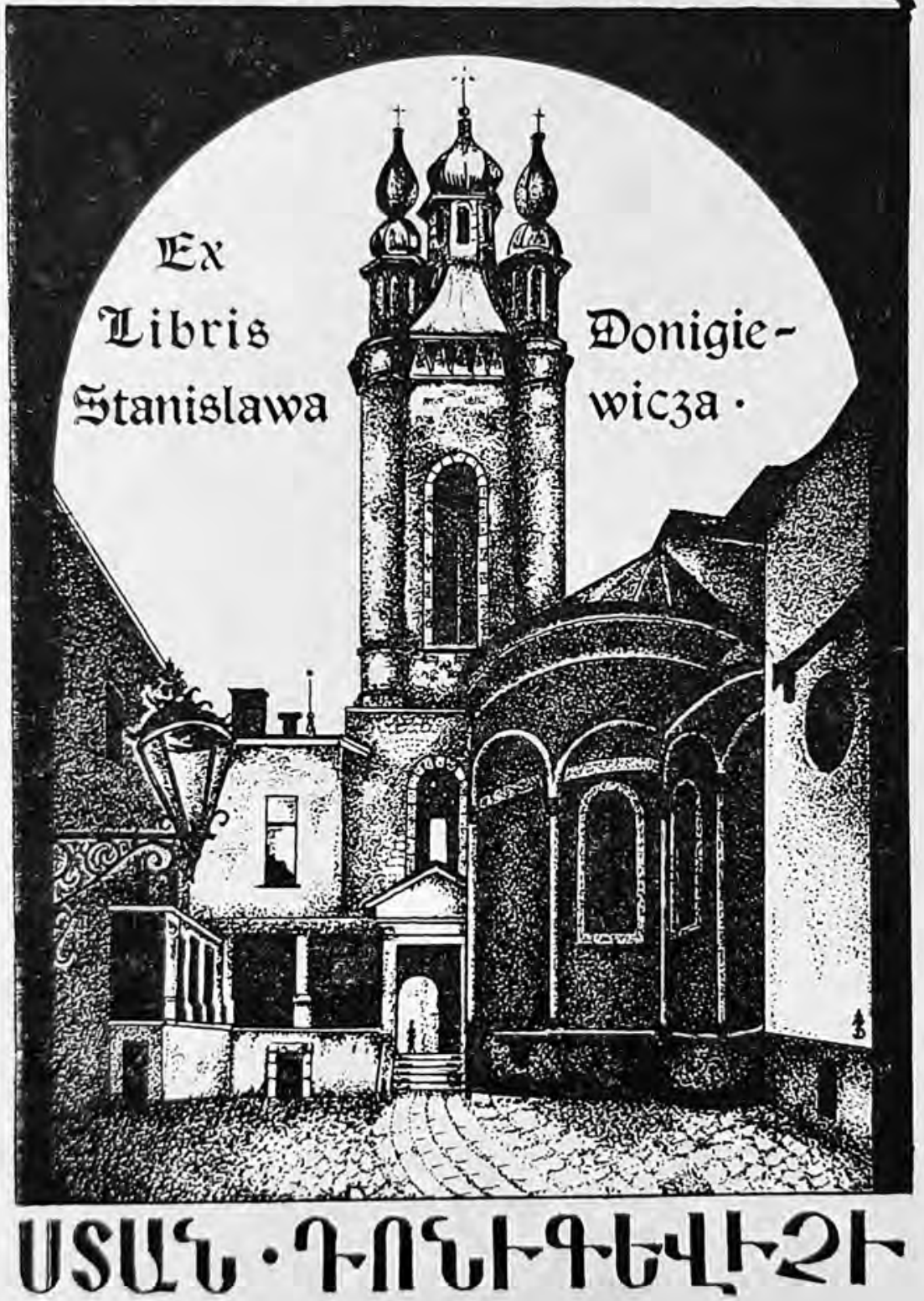

15. Jan Hasso Agopsowicz, ekslibris Stanisława Donigiewicza, 1977, cynkotypia, zbiory autora 


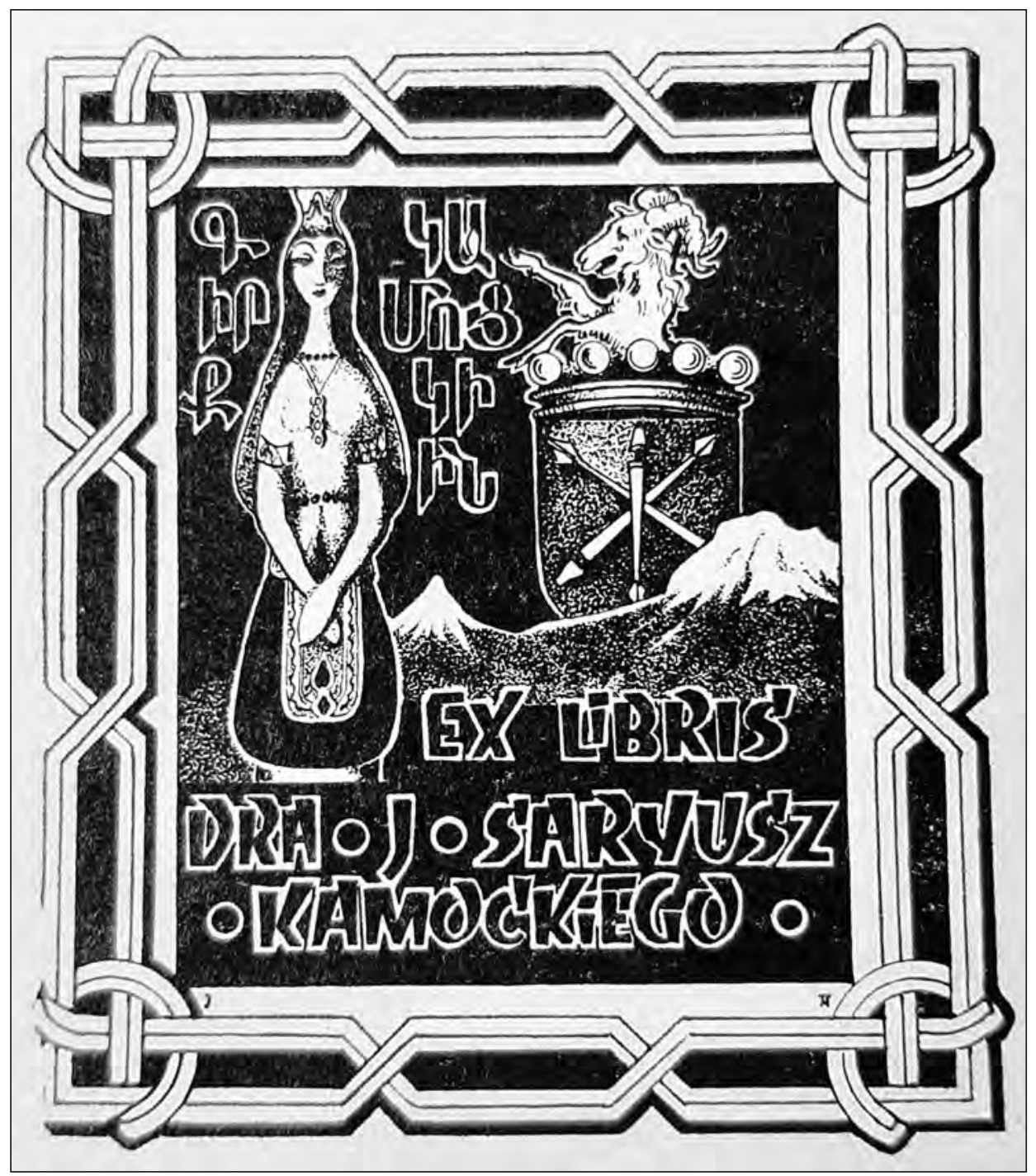

16. Jan Hasso Agopsowicz, ekslibris Janusza Kamockiego, 1971, cynkotypia, zbiory autora 


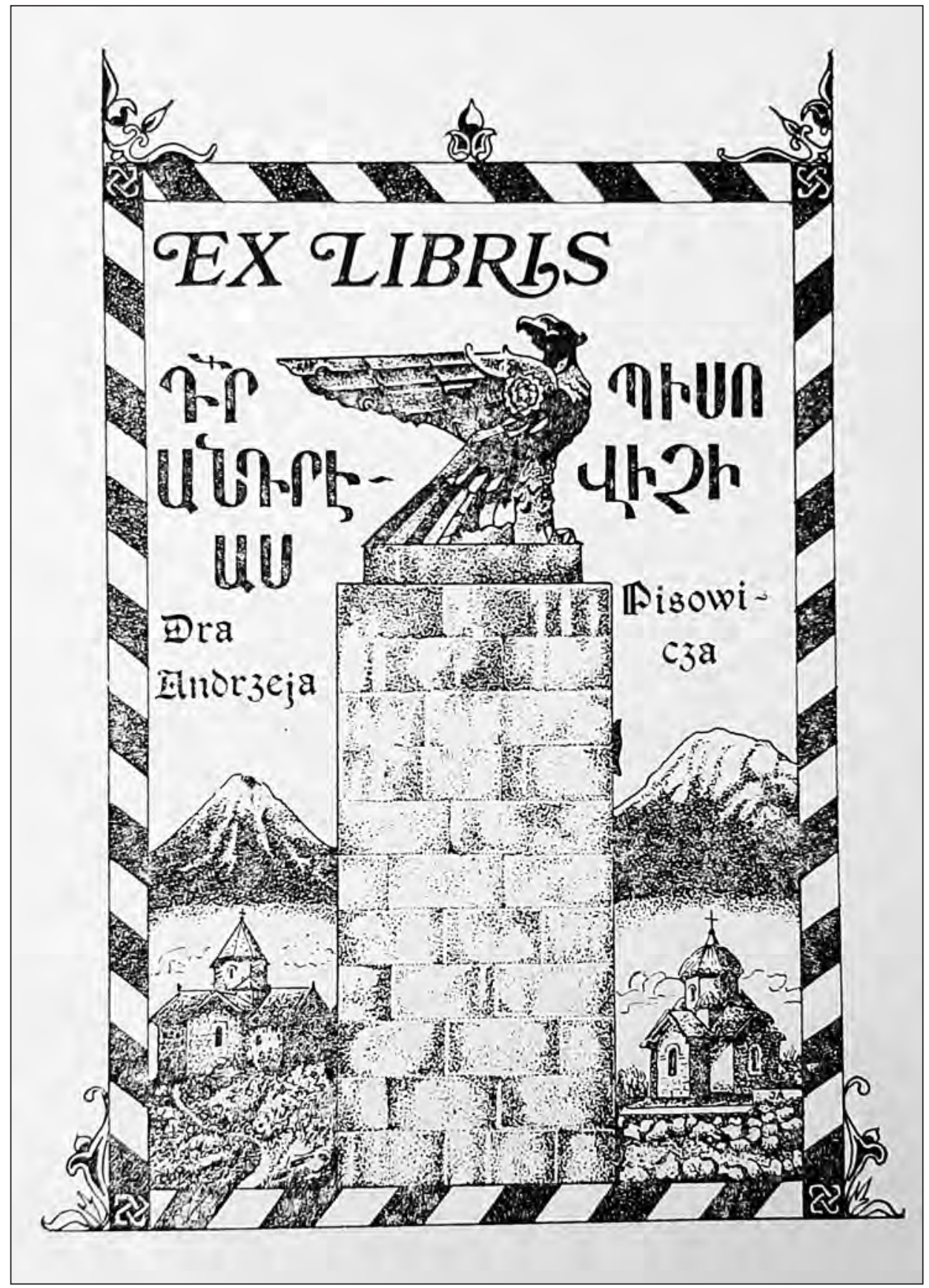

17. Jan Hasso Agopsowicz, ekslibris Andrzeja Pisowicza, 1977, cynkotypia, zbiory autora 


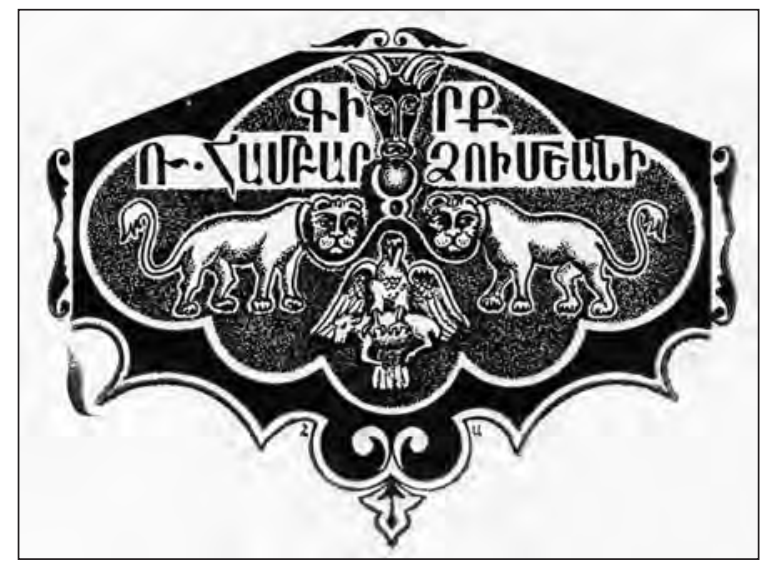

18. Jan Hasso Agopsowicz, ekslibris Rafaela Hambarcumiana, 1978, cynkotypia, zbiory dr. Tomasza Sumy

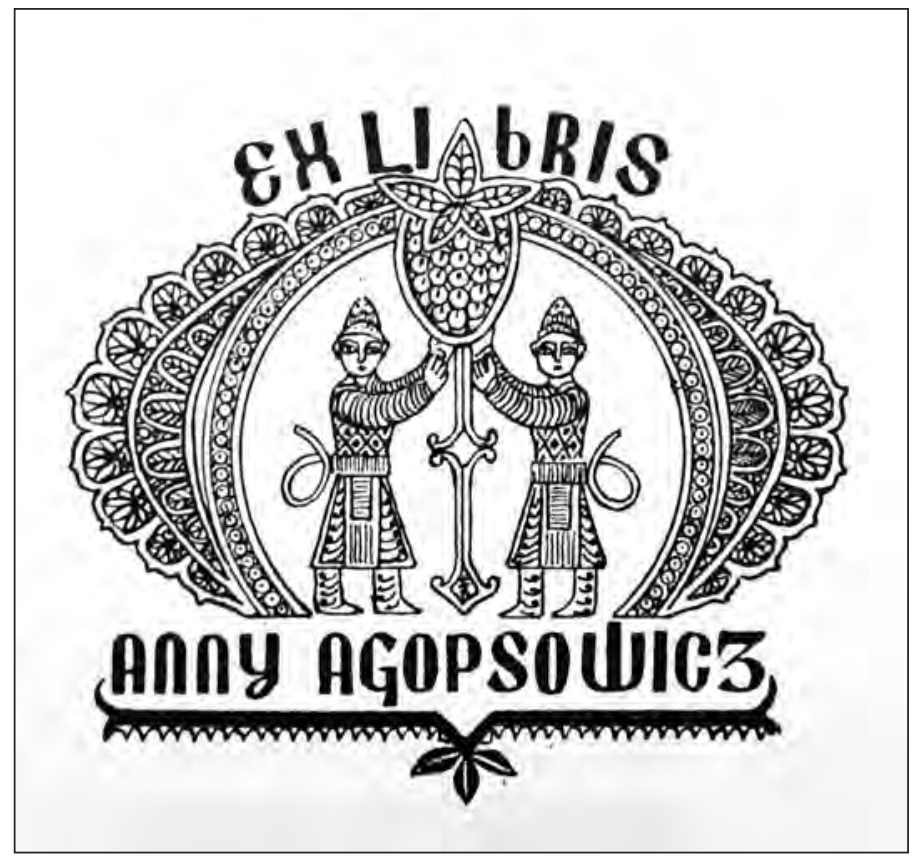

19. Jan Hasso Agopsowicz, ekslibris Anny Agopsowicz, 1976, cynkotypia, zbiory Fundacji Kultury i Dziedzictwa Ormian Polskich w Warszawie 




20. Jan Hasso Agopsowicz, ekslibris Feliksa Ścibałły, 1962, cynkotypia, zbiory autora 